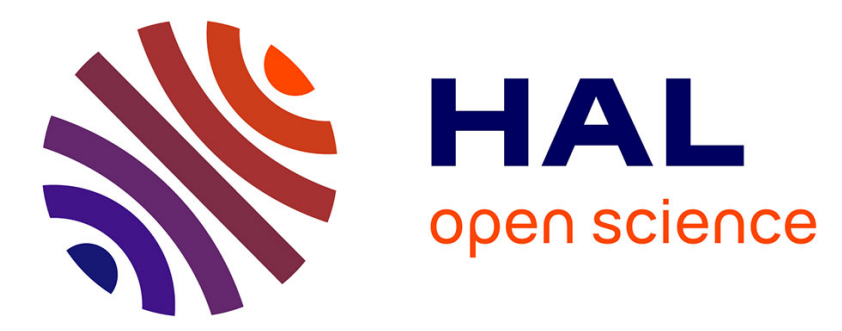

\title{
$\alpha$-Hydroxy-Tetrazoles as Latent Ethynyl Moieties: A Mechanistic Investigation
}

Pierre Quinodoz, Karen Wright, Bruno Drouillat, Mikhail Kletskii, Oleg Burov, Anton. Lisovin, François Couty

\section{To cite this version:}

Pierre Quinodoz, Karen Wright, Bruno Drouillat, Mikhail Kletskii, Oleg Burov, et al.. $\alpha$-HydroxyTetrazoles as Latent Ethynyl Moieties: A Mechanistic Investigation. European Journal of Organic Chemistry, 2019, Organic Reaction Mechanisms, 2019 (2-3), pp.342-350. 10.1002/ejoc.201800143 . hal-02348773

\section{HAL Id: hal-02348773 \\ https://hal.science/hal-02348773}

Submitted on 29 Jul 2021

HAL is a multi-disciplinary open access archive for the deposit and dissemination of scientific research documents, whether they are published or not. The documents may come from teaching and research institutions in France or abroad, or from public or private research centers.
L'archive ouverte pluridisciplinaire HAL, est destinée au dépôt et à la diffusion de documents scientifiques de niveau recherche, publiés ou non, émanant des établissements d'enseignement et de recherche français ou étrangers, des laboratoires publics ou privés. 
This is the peer reviewed version of the following article: Quinodoz, P., Wright, K. , Drouillat, B., Kletskii, M. E., Burov, O. N., Lisovin, A.V. and Couty, F. (2019), Alpha hydroxy tetrazoles as latent ethynyl moieties: a mechanistic investigation. Eur. J. Org. Chem., 2019: 342-350. doi: 10.1002/ejoc.201800143, which has been published in final form at https://doi.org/10.1002/ejoc.201800143. This article may be used for non-commercial purposes in accordance with Wiley Terms and Conditions for Use of Self-Archived Versions.

\title{
Alpha hydroxy tetrazoles as latent ethynyl moieties: a mechanistic
}

\section{investigation}

\author{
Pierre Quinodoz, ${ }^{[a]}$ Karen Wright, ${ }^{[a]}$ Bruno Drouillat, ${ }^{[a]}$ Mikhail E. Kletskii, ${ }^{[b]}$ Oleg N. Burov, ${ }^{[b]}$ Anton. V. \\ Lisovin, ${ }^{[b]}$ and François Couty* ${ }^{* a]}$
}

\begin{abstract}
This article focuses on the dehydration of alpha hydroxy tetrazoles, leading to tetraazafulvenes and then to vinylic carbenes, that rearrange into ethynyl moieties through the Fritsch-ButtenbergWiechell (FBW) rearrangement. Each step of this sequence was scrutinized, either through examination of the substrate and/or dehydrating agent scope, or through AM1 calculations, in order to understand the limiting step of this process. This underrated transformation appears to be a viable alternative to the existing methods used to transform an aldehyde into an alkyne.
\end{abstract}

\section{Introduction}

Following the seminal work of Colvin ${ }^{1}$ and Corey-Fuchs ${ }^{2}$ who reported in the early 70's the two-step sequence to transform a carbonyl compound into an alkyne, this very useful synthetic transformation has been thoroughly studied and recently reviewed. ${ }^{3}$ Most of these methods rely on the generation of an intermediate vinyl carbene, which rearranges through the Fritsch-Buttenberg-Wiechell (FBW) rearrangement. In this field, Seyferth-Gilbert, ${ }^{4}$ or Ohira-Bestmann ${ }^{5}$ reagents and their variants ${ }^{6}$ have become popular for this transformation. Though the scope of all these existing tools cover the vast majority of substrates, some drawbacks still remain such as the need for a base in the process, the cost of the reagents, and the hazards associated with diazo compounds. Thus, new procedures for this transformation are still highly desirable.

Alpha hydroxy tetrazoles (AHTs) were reported as early as $1966^{7}$ to dehydrate upon heating, or under the action of DCC, generating vinyl carbenes after expulsion of dinitrogen. Alternatively, alpha cyano mesylates were reported to generate vinyl carbenes via decomposition of derived intermediate tetrazoles. ${ }^{8}$ However such reactions have been scarcely used as synthetic tools, until Wardrop ${ }^{9}$ reported its use for the generation of vinyl carbenes, evolving either through FBW rearrangement or insertion reactions. We have recently shown that alpha-hydroxy-beta azido tetrazoles (AHBAT) can be used as one carbon atom staples for orthogonal double CuAAC ligations, this procedure involving in a key-step the mild generation of an alkyne from an AHT through EDC or DIC treatment. $^{10}$

[a] Institut Lavoisier de Versailles, UMR 8180 Université de Versailles St-Quentin-en-Yvelines, Université Paris Saclay. 45 av. des Etats-Unis, 78035 Versailles Cedex, France E-mail: couty@chimie.uvsq.fr; http://www.ilv.uvsq.fr Fax: +33 (0)13925 4452

[b] Department of Chemistry, Southern Federal University, 7, Zorge St., 344090, Rostov-on-Don, Russian Federation
These studies suggested an alternative pathway to transform an aldehyde into an alkyne which involves: (i) transformation of the aldehyde into an AHT, and (ii) its dehydration; this generates a tetraazafulvene which then expulses two molecules of $\mathrm{N}_{2}$ to generate the vinyl carbine, and finally evolves to the alkyne through FBW rearrangement (Scheme 1).

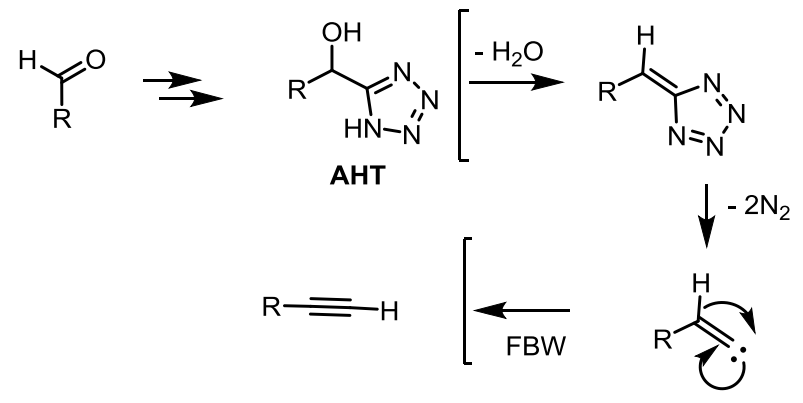

Scheme 1. General scheme for the transformation of AHTs into alkynes.

This two step sequence is particularly appealing for several reasons. First, many routes are available to produce AHTs from aldehydes. Also, the second step appears to be ideal in terms of waste by-products, since only water and dinitrogen are produced. Finally, this dehydration does not imply the use of a base, contrary to the aforementioned methods. This article aims to study the feasibility of this transformation, focusing on the dehydration step, and answer the inherent questions about its scope and detailed mechanism.

\section{Results}

In order to study the scope of this transformation, we first had to select an array of representative AHTs. Synthesis of such compounds is well documented and involves different disconnections starting from either alpha-keto tetrazoles, ${ }^{11}$ carbonyl compounds, ${ }^{12}$ cyanoepoxides, ${ }^{13}$ or cyanohydrins. ${ }^{14}$ Since direct synthesis from carbonyl compounds leads to $\mathrm{N}$ protected tetrazoles, thus implying an additional deprotection step, we selected the as yet unexplored route involving formation of an intermediate OTMS cyanohydrin, formed upon reaction of the aldehyde with $\mathrm{TMSCN}$ and $\mathrm{Et}_{3} \mathrm{~N}$ (cat.). Subsequent cycloaddition with $\mathrm{TMSN}_{3}$ catalyzed by $\mathrm{Bu}_{2} \mathrm{SnO}$ gave the tetrazoles. This reaction was conducted in one pot, 
yielding after mild desilylation in acidic medium the AHTs 1-16 in good overall yields. It is noteworthy that the potential cycloaddition on the aromatic nitrile in $\mathbf{2}$ is very slow under these reaction conditions, so that the tetrazole was formed selectively on the cyanohydrin. Only one limitation was found with an alpha disubstituted aldehyde, which failed to give tetrazole 7 , probably for steric reasons (Figure 1). The series 5-16 was designed in order to detect possible participation of a moiety present in the side-chain (amine or carbamate), in the crucial elimination step (vide infra). Additionally, AHTs 17-19 were prepared from AHBATs, ${ }^{13}$ and 20 was prepared in excellent yield (91\%) by addition of phenyllithium on the corresponding benzoyl tetrazole.

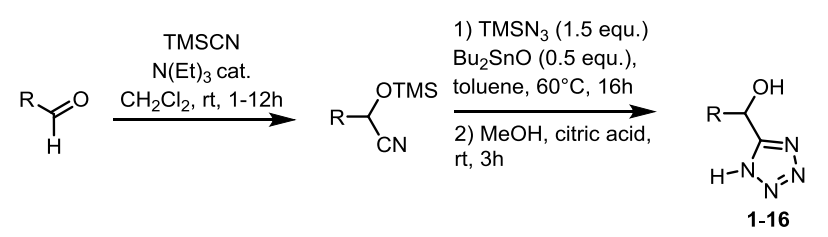

Aromatic aldehydes

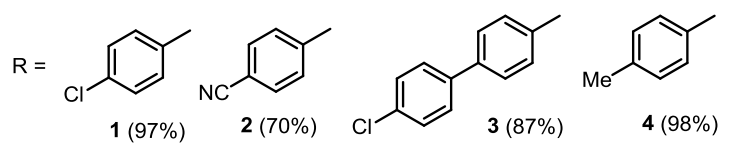

Aliphatic and functionnalized aldehydes

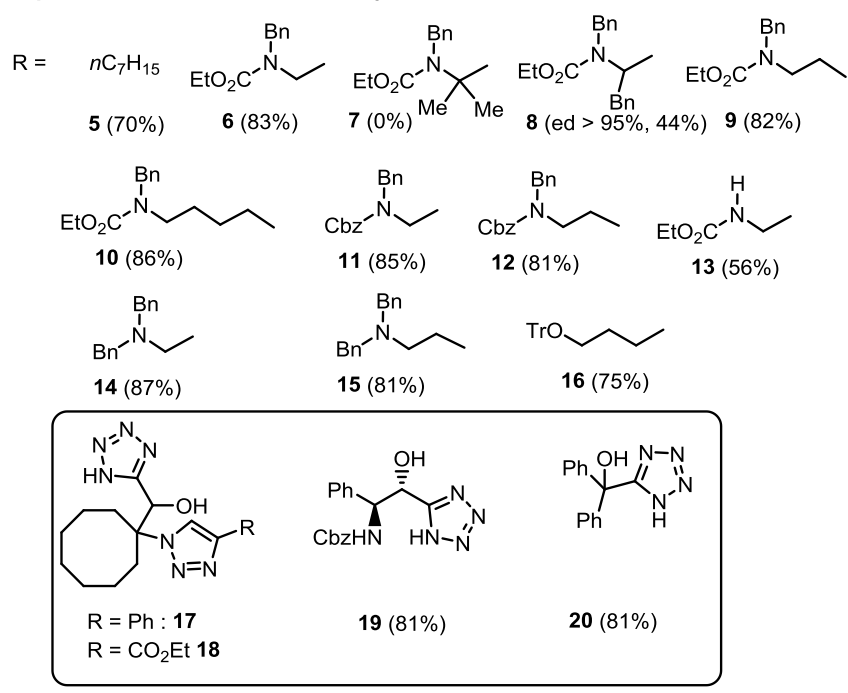

Figure 1. Structures of AHTs 1-16 prepared via OTMS cyanohydrins, and of AHTs 17-20, prepared by other procedures.

It should be pointed out here that in order to promote the dehydration step of an AHT and ultimately produce the alkyne, two routes are possible: activation of the hydroxyl moiety in the cyanohydrin before the cycloaddition step leading to the tetrazole, or, as will be discussed here, activation of the hydroxyl in the AHT after cycloaddition. A very successful example of the first route has been recently disclosed by Harusawa et $\left.a\right|^{15}$ and involves activation of the hydroxyl as a phosphonate. The efficiency of this process, based on the facile preparation of cyanophosphonates from carbonyl compounds, demonstrates that tetrazoles fitted with an alpha leaving group are indeed latent alkynes, and nicely complements the available tools mentioned in the introduction. For our part, we explored briefly this possibility starting from either cyanocarbonates or cyanomesylates, ${ }^{8}$ but without much success, since yields of alkynes culminated around $20 \%$. A single set of experiments should however be mentioned here, which illustrates that this reaction can be highly substrate-dependent. While alkyne 22 was produced from benzylic cyanocarbonate 21, albeit in low yield, aliphatic cyanocarbonate $\mathbf{2 3}$ gave only the corresponding tetrazole 24 without a trace of alkyne under the same cycloaddition conditions (Scheme 2).

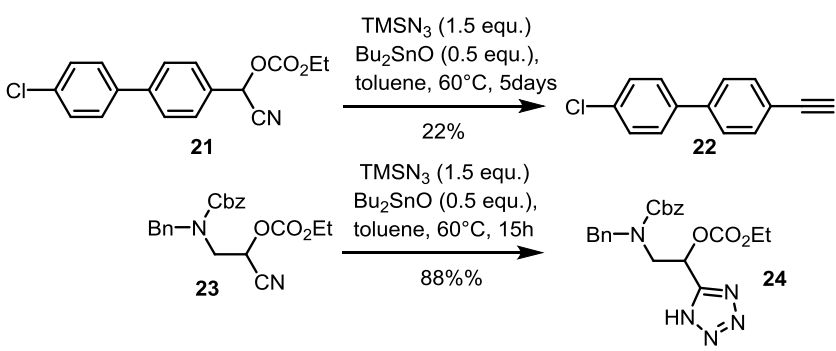

Scheme 2. Different behaviour of aliphatic and benzylic cyanocarbonates in cycloaddition conditions.

Let us now focus on the dehydration step of AHTs, leading to the corresponding ethynyl moiety. For the preliminary screening of the dehydrating agent, we first selected an array of four AHTs: 3,6 and 17/18, fitted either with a benzylic or aliphatic group at the hydroxyl position. Compounds 17/18 were reported by us to produce efficiently an alkyne upon treatment with DIC. ${ }^{10}$

Numerous dehydrating or activating reagents were tested with these substrates, including carbodiimides, peptide coupling reagents (such as HATU, BOP, or EEDQ), fluorination reagents (DAST, X-talFluor), Burgess's reagent, Martin's sulfurane, $\mathrm{SOCl}_{2}$, Appel's reagent, with contrasting results. This large screening led us to focus on two standardized reactions, selected for their ability to produce the expected alkynes and their easy implementation. They include treatment with DIC (1.2 eq., DCM, rt, 24h), and with DAST, diethylaminosulfur trifluoride, (1.5 eq., DIPEA, 1 eq., DCM, $0^{\circ} \mathrm{C}, 1 \mathrm{~h}$ ). The following Table 1 records the yields (\%) of, unless otherwise stated, isolated alkynes 1a-6a and 12a-20a

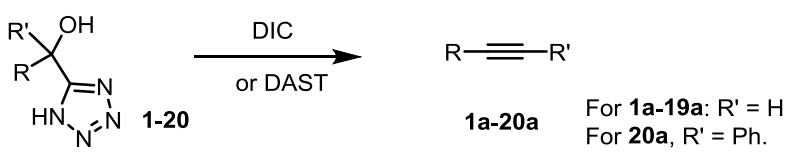

\begin{tabular}{cccc} 
AHT & DIC & DAST & Alkyne \\
\hline $\mathbf{1}$ & $30^{\mathrm{a}}$ & $26^{\mathrm{a}}$ & $\mathbf{1 a}$ \\
$\mathbf{2}$ & $47^{\mathrm{a}}$ & $32^{\mathrm{a}}$ & $\mathbf{2 a}$ \\
$\mathbf{3}$ & 0 & $12^{\mathrm{a}}$ & $\mathbf{3 a}$ \\
$\mathbf{4}$ & 8 & trace & $\mathbf{4 a}$ \\
$\mathbf{5}$ & $42^{\mathrm{a}}$ & $57^{\mathrm{a}}$ & $\mathbf{5 a}$
\end{tabular}




\begin{tabular}{cccc}
$\mathbf{6}$ & 52 & 70 & $\mathbf{6 a}$ \\
$\mathbf{8}$ & 59 & 57 & $\mathbf{8 a}$ \\
$\mathbf{9}$ & 29 & 43 & $\mathbf{9 a}$ \\
$\mathbf{1 0}$ & $\mathrm{nt}$ & 44 & $\mathbf{1 0 a}$ \\
$\mathbf{1 1}$ & 60 & 61 & $\mathbf{1 1 a}$ \\
$\mathbf{1 2}$ & $\mathrm{nt}$ & $\mathrm{nt}$ & $\mathbf{1 2 a}$ \\
$\mathbf{1 3}$ & $\mathrm{nt}$ & trace & $\mathbf{1 3 a}$ \\
$\mathbf{1 4}$ & trace & trace & $\mathbf{1 4 a}$ \\
$\mathbf{1 5}$ & $\mathrm{nt}$ & 20 & $\mathbf{1 5 a}$ \\
$\mathbf{1 6}$ & 39 & 64 & $\mathbf{1 6 a}$ \\
$\mathbf{1 7}$ & 73 & $78^{\mathrm{b}}$ & $\mathbf{1 7 a}$ \\
$\mathbf{1 8}$ & 64 & nt & $\mathbf{1 8 a}$ \\
$\mathbf{1 9}$ & 65 & 60 & $\mathbf{1 9 a}$ \\
$\mathbf{2 0}$ & 80 & 70 & $\mathbf{2 0 a}$ \\
\hline a & Yield determined by NMR, with an internal standard \\
(trimethoxybenzene or mesitylene). ${ }^{\mathrm{b}}$ Pyridine was used instead of \\
DIPEA. nt: not tested.
\end{tabular}

Thionyl chloride was also used as activating agent, but this reagent did not produce any alkyne. In place, 5-tetrazoyl oxazolidinone $\mathbf{2 5}$ or oxazinanone $\mathbf{2 6}$ were produced in good yields from 11 and 12 respectively (Scheme 3).

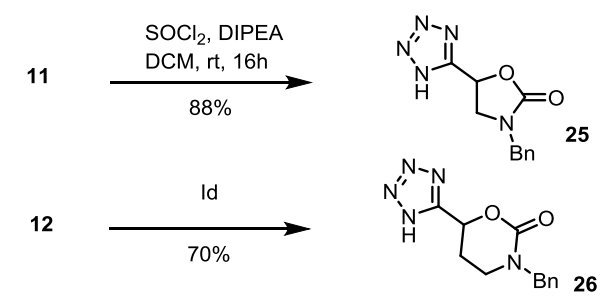

Scheme 3. Thionyl chloride activation of $\mathbf{1 1}$ or $\mathbf{1 2}$ produces $\mathbf{2 5}$ or $\mathbf{2 6}$

\section{Discussion}

It appears that DIC and DAST are both suitable activating agents, able to produce the alkyne from AHT, but yields are greatly dependent on the type of substrate used. Three types of substrates can be classified: first, with benzylic substrates 1-4, yields are consistently low, always below 50\%, though increasing when electron-withdrawing groups are present on the aromatic ring; with aliphatic compounds $5,9,10,16$, either devoid of a moiety able to participate in the elimination process in the side-chain, or remote from the carbon bearing the hydroxyl, yields are modest (around 50\%) and DAST appears to be slightly more efficient than DIC. Finally, with compounds $6,8,11$ and 17-19, all fitted with a nucleophilic moiety ( $N$-carbamate or triazole), alpha to the hydroxylated carbon, yields are much higher, near or above $60 \%$, and our previously reported AHBAT 17-18 substrates appear to be privileged compounds for this transformation. ${ }^{10}$ The presence of a tertiary amine, such as in 14-15 was however not compatible with these conditions. The case of AHT 20, fitted with a quaternary benzylic position, and leading to diphenyl acetylene 20 a in excellent yield is perfectly in line with the report of Wardrop, ${ }^{9}$ and contrasts with the poor yields obtained in the first series 1-4. These results led us to focus on the mechanism of the elimination step, which might be the limiting one in the overall process, since the efficiency of the reaction seems to be higher in the case of moieties able to participate via an $\mathrm{S}_{\mathrm{N}} \mathrm{i}$ mechanism, and promote elimination. First, to gain insight into the detailed mechanism of the reaction with DIC, the elimination step (C $\rightarrow \mathbf{D}+\mathbf{E}$ ) in model substrate $\mathbf{A}$ leading to tetraazafulvene $\mathbf{D}$ and urea $\mathbf{E}$ was computed through PCM quantum chemical calculations (PBE0/6-31++G(d,p) level of theory, see $\mathrm{SI})$. This process requires an activation energy of $23.9 \mathrm{kcal} . \mathrm{mol}^{-1}$, and can therefore readily occur at rt. Produced tetraazafulvene $\mathbf{D}$ and urea $\mathbf{E}$ lie at higher energy $(21.1 \mathrm{kcal} . \mathrm{mol}$ $\left.{ }^{1}\right)$ than the initial system, reflecting the loss of aromaticity of the heterocycle (Figure 2). It should be noted that the acidity of the tetrazole is a very important parameter for the success of the reaction, allowing acidic catalysis for the initial nucleophilic addition of the hydroxyl on the carbodiimide. ${ }^{16}$
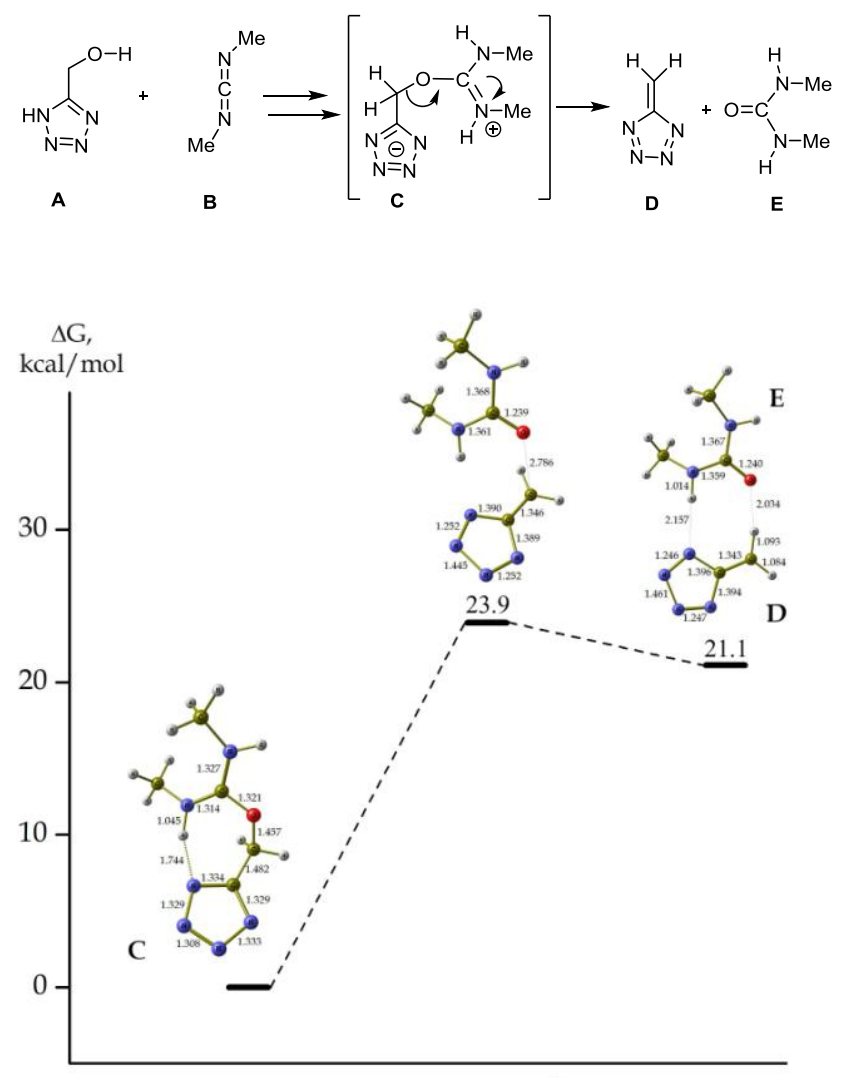

Reaction coordinate

Figure 2. Relative Gibbs free energies $(\Delta G)$ along the course of model elimination step in $\mathbf{C}$. Process stoichiometry was taken into account. Calculated geometries of the main stationary points (interatomic distances in Å). PCM/PBE0/6-311++G(d,p), calculations in dichloromethane.

Decomposition of model tetraazafulvene $\mathbf{D}$ into the corresponding vinyl carbene $\mathbf{G}$ was also computed at the same level of theory in simulated DCM. Calculations show that this is a stepwise process going through the intermediate diazoalkene $\mathbf{F}$. The overall process is highly exothermic and requires 9.7 $\mathrm{kcal} . \mathrm{mol}^{-1}$ for the first activation step, and $11.4 \mathrm{kcal}^{\mathrm{mol}}{ }^{-1}$ for the 
second one, which is significantly lower than the dehydration step (Figure 3). Though we were not able to isolate or characterize by NMR any tetraazafulvene or diazoalkene, such intermediates can be detected by high resolution mass spectroscopy analysis (ESI) of AHTs such as $\mathbf{1}$ and $\mathbf{3}$, suggesting a non-negligible lifetime.
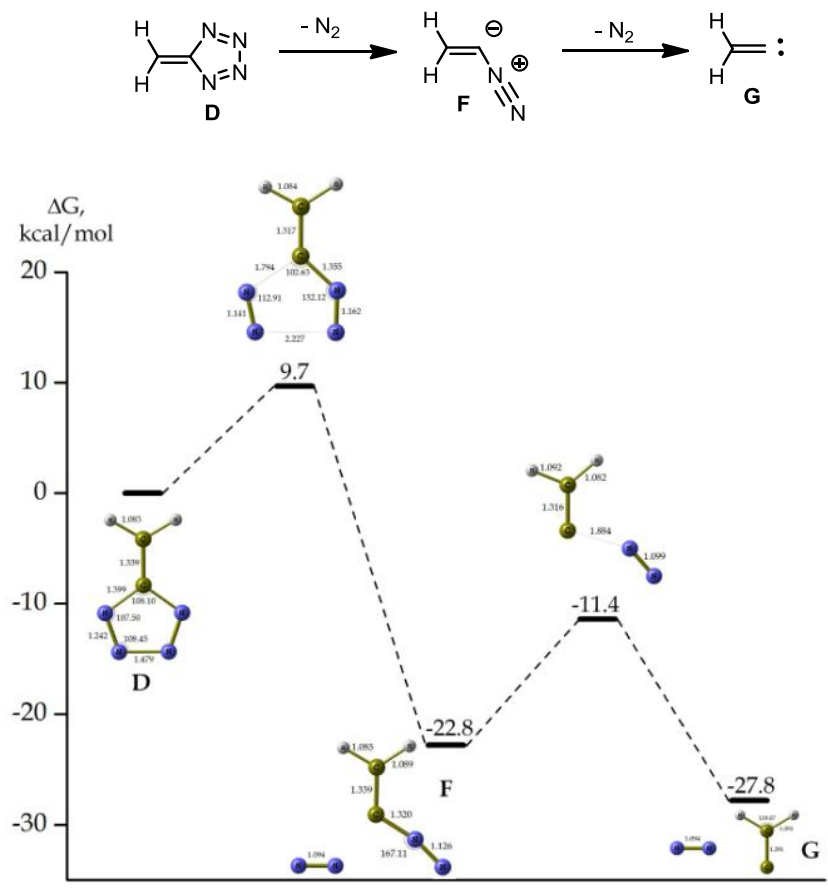

Reaction coordinate

Figure 3. Relative Gibbs free energies $(\Delta G)$ along the course of the model elimination step of $\mathrm{N}_{2}$ in $\mathbf{D}$. Process stoichiometry was taken into account. Calculated geometries of the main stationary points: interatomic distances in $\AA$, valence angles in degrees. PCM/PBE0/6-31++G(d,p) calculations in dichloromethane.

A general trend can thus be outlined from these experimental and theoretical results: the first step of this transformation (dehydration or AHT decomposition into urea and tetraazafulvalene) appears to be the rate-limiting one. In order to best fit with our tested substrates, further calculations were conducted with AHTs 27, mimicking a simplified 17/18 (Scheme 4), 11 and 20. For these compounds, the activation energies for the steps leading to the corresponding tetraazafulvene when reacting with dimethylcarbodiimide were determined. Model compound 27, which is the structural analogue of derivatives 17 and 18 , required $23.6 \mathrm{kcal}^{\mathrm{mol}}{ }^{-1}$ to eliminate the urea, which is close to the value for compound $11\left(20.3 \mathrm{kcal}^{\mathrm{mol}}{ }^{-1}\right)$. These values are in line with simplified model $\mathbf{A}$, which requires 23.9 $\mathrm{kcal} . \mathrm{mol}^{-1}$ (Figure 2). Remarkably, 20 required only $6.8 \mathrm{kcal}^{\mathrm{mol}}{ }^{-1}$, thus highlighting the positive effect of an additional phenyl group to promote dehydration. It should be noted that calculation showed that tetraazafulvene 29 , resulting from 11 , collapses spontaneously to zwitterionic compound $\mathbf{3 0}$, thus demonstrating that such a tetraazafulvene can act as a Michael acceptor with a nucleophile (an internal carbamate in this case), thereby restoring the aromaticity of the tetrazolate (Scheme 4). This process explains the formation of $\mathbf{2 5}$ and $\mathbf{2 6}$ (Scheme 3) upon activation with thionyl chloride. In these cases, the chloride anion attacks the O-benzyl group in $\mathbf{3 0}$, producing the oxazolidinone, or the homologous oxazinanone. This propensity of intermediate tetraazafulvenes to act as Michael acceptors might also explain the low yields obtained in the case of benzylic AHTs 1-4. With these substrates, conjugation in the produced tetraazafulvenes might stabilize these intermediates and extend their lifetime, thus allowing competitive Michael addition with nucleophiles present in the reaction medium. Although we could not isolate such adducts, LCMS analysis of the crude reaction mixture resulting from reaction of $\mathbf{3}$ with EDC in DCM showed that the major detected product was an adduct between EDC and 3, which might result from Michael addition of the produced urea on the tetraazafulvene. Furthermore, by running the reaction in $\mathrm{MeOH}$ instead of $\mathrm{DCM}$, compound 31, probably resulting from Michael addition of methanol on the intermediate tetraazafulvene, was isolated in fair yield (Scheme 5).

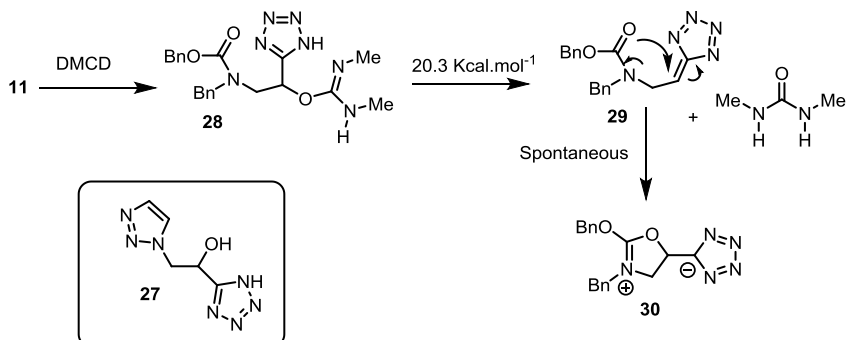

Scheme 4. Computed elimination from AHT 11 leads to an intermediate tetraazafulvene that spontaneously reacts through intramolecular Michael addition with a nearby carbamate.

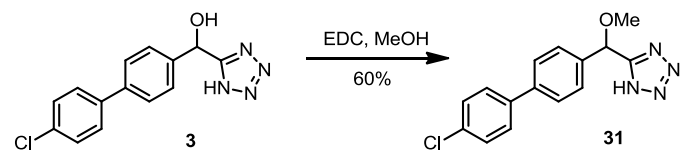

Scheme 5. Formation of alpha-OMe tetrazole $\mathbf{3 1}$ is observed when dehydration of $\mathbf{3}$ is conducted in $\mathrm{MeOH}$.

Activation with DAST appeared also to be an efficient means to promote this reaction. We found that addition of 1 equiv. of a base, DIPEA, was necessary to attain good yields: this is best illustrated with substrate 11 reacting with DAST, with or without this added base: with DIPEA, the expected alkyne 11b was produced in $61 \%$ yield, along with $15 \%$ of 32 , while an unseparable mixture of tetrazole regioisomers 32 (43:57) was exclusively produced without DIPEA (Scheme 6). 


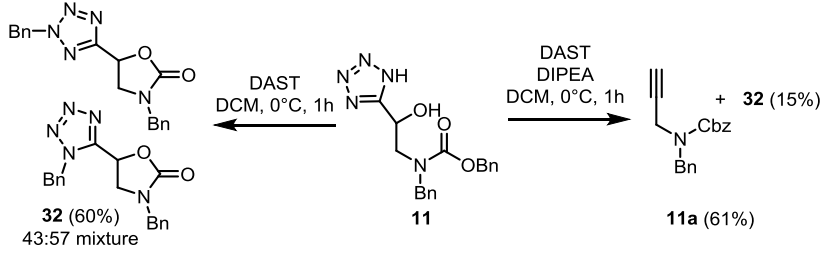

Scheme 6. The addition of a base (DIPEA) is important to attain good yields of alkyne upon treatment with DAST.

Regioisomers 32 are produced by nucleophilic substitution involving two molecules of zwitterion $\mathbf{3 0}$, or its protonated form $30+\mathrm{H}^{+}$(Scheme 7). Thus, if the medium remains acidic (reaction of the hydroxyl with DAST produces one equivalent of HF), substantial amounts of $30+\mathrm{H}^{+}$are obtained, precluding back formation to tetraazafulvene $\mathbf{2 9}$ and its further decomposition to 11b. The aforementioned bimolecular reaction can therefore occur at a reasonable rate to give $\mathbf{3 2}$. Thus, this result questions the reversibility of $\mathbf{3 0}$ leading to 29 .

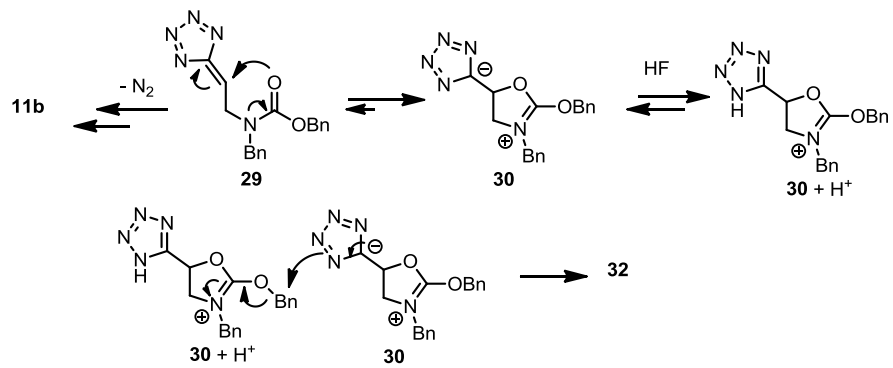

Scheme 7. A plausible mechanism for the formation of 32 .

\section{Conclusions}

In conclusion, we have studied in detail the dehydration of AHTs, leading ultimately to alkynes. Carbodiimides and DAST/DIPEA were identified as suitable activation reagents to promote this process. The two-step transformation of aldehydes into AHTs, followed by dehydration and evolution to the alkyne appears to be a viable process with a reasonable scope of aldehydes, especially those fitted with an alpha carbamate or triazole. Computational studies of the involved mechanism demonstrated that the limiting step is the initial dehydration (or AHT decomposition into urea and tetraazafulvalene) leading to an intermediate tetraazafulvene. The latter evolves through a stepwise mechanism to the carbene via sequential expulsion of two molecules of dinitrogen, and might, in some cases, react as a Michael acceptor in a competing way. This procedure complements the existing tools for the transformation of aldehydes into ethynyl moieties and can be performed under very mild conditions.

\section{Experimental Section}

General information: ${ }^{1} \mathrm{H}$ and ${ }^{13} \mathrm{C}$ NMR spectra were recorded at 200 or 300 and $75 \mathrm{MHz}$, respectively; chemical shifts $(\delta)$ are reported in ppm and coupling constants $(J)$ reported in Hertz and rounded up to $0.1 \mathrm{~Hz}$. Splitting patterns are abbreviated as follows: singlet (s), doublet (d), triplet $(\mathrm{t})$, quartet $(\mathrm{q})$, septuplet (sep), multiplet $(\mathrm{m})$, broad (br), or a combination of these. Solvents were used as internal standard when assigning NMR spectra ( $\left.\delta \mathrm{H}: \mathrm{CDCl}_{3} 7.26 \mathrm{ppm} ; \delta \mathrm{C}: \mathrm{CDCl}_{3} 77.0 \mathrm{ppm}\right)$. Assignments for signals from ${ }^{1} \mathrm{H}$ and ${ }^{13} \mathrm{C}$ in the NMR spectra were validated by two-dimensional correlated spectroscopy (2D COSY) and Heteronuclear Multiple Bond Correlation (HMBC). IR data were collected with an ATR-FT-IR spectrometer. All reactions were carried out under argon. DCM was distilled from $\mathrm{CaH}_{2}$. Column chromatography was performed on silica gel (230-400 mesh) with use of various mixtures of $\mathrm{CH}_{2} \mathrm{Cl}_{2}$, EtOAc, petroleum ether $\left(35-60^{\circ} \mathrm{C}\right.$ fraction) (PE) and methanol. TLC was performed on Merck Kieselgel 60 F254 plates. Melting points are uncorrected. Isomeric ratios were determined by NMR analysis of crude reaction mixtures before purification.

All reactions were performed on $1 \mathrm{mmol}$ scale.

\section{General procedure for the synthesis of AHT}

\section{Cyanohydrin formation}

In a dried round-bottomed flask, the aldehyde (1 eq.) was dissolved in $\operatorname{DCM}(2 \mathrm{~mL} / \mathrm{mmol})$. TMSCN (1.2 eq.) and triethylamine $(0.2$ eq.) were then added and the mixture was stirred for 30 minutes at room temperature. The solvent was then removed and the crude used directly for the cycloaddition step. For 21 and 23, ethylcyanoformate was used instead of TMSCN and the crude product purified by flash chromatography over silica gel using a PE/EtOAc mixture as eluent. For 14 and 15, the silylated cyanohydrin was purified by flash chromatography over silica gel using a PE/EtOAc mixture as eluent and the non-substituted cyanhohydrin was obtained.

\section{Cycloaddtion}

In a dried round-bottomed flask, the cyanohydrin was dissolved in toluene $(5 \mathrm{~mL} / \mathrm{mmol})$. After the addition of $\mathrm{Bu}_{2} \mathrm{SnO}\left(0.5\right.$ eq.) and $\mathrm{TMSN}_{3}$ (1.5 eq.), the mixture was stirred at $60^{\circ} \mathrm{C}$ until complete conversion (usually 24h) and the residue was purified by flash chromatography over silica gel using a $\mathrm{DCM} / \mathrm{MeOH} / \mathrm{AcOH}$ mixture as eluent.

\section{(4-Chlorophenyl)(1H-tetrazol-5-yl)methanol 1}

White solid (97\%); $\mathrm{Mp}: 187-189^{\circ} \mathrm{C}$ (dec.) $\mathrm{Rf}=0.15(\mathrm{DCM} / \mathrm{MeOH} / \mathrm{AcOH}$ 97/3/2); ${ }^{1} \mathrm{H}$ NMR $\left(300 \mathrm{MHz}, \mathrm{CDCl}_{3}\right.$ ): $\delta=7.35(\mathrm{~d}, J=8.5 \mathrm{~Hz}, 2 \mathrm{H}, \mathrm{Ar}), 7.28$ $(\mathrm{d}, J=8.6 \mathrm{~Hz}, 2 \mathrm{H}, \mathrm{Ar}), 6.05(\mathrm{~s}, 1 \mathrm{H}, \mathrm{CHOH}) \mathrm{ppm} .{ }^{13} \mathrm{C} \mathrm{NMR}(75 \mathrm{MHz}$, $\left.\mathrm{CDCl}_{3}\right): \delta=160.73\left(\mathrm{C}_{\mathrm{q}}\right), 140.56\left(\mathrm{C}_{\mathrm{q}}\right), 135.28\left(\mathrm{C}_{\mathrm{q}}\right), 129.83\left(\mathrm{C}_{\mathrm{Ar}}\right), 129.14$ $\left(\mathrm{C}_{\mathrm{Ar}}\right), 67.85(\mathrm{CHOH})$ ppm. IR: vmax $=3344,1568,1489,1250,1052,786$, $614 \mathrm{~cm}^{-1}$. HRMS (TOF MSES positive mode) $\mathrm{m} / z$ calcd. for $\mathrm{C}_{8} \mathrm{H}_{8} \mathrm{CIN}_{4} \mathrm{O}$ $[\mathrm{MH}]^{+}: 211.0395$; found : 211.0395 .

\section{(4-Cyano)(1H-tetrazol-5-yl)methanol 2}

White solid (70\%); $\mathrm{Mp}: 139-141^{\circ} \mathrm{C}$ (dec.); $\mathrm{Rf}=0.15(\mathrm{DCM} / \mathrm{MeOH} / \mathrm{AcOH}$ 97/3/2); ${ }^{1} \mathrm{H}$ NMR (300 MHz, MeOD): $\delta=7.77$ (d, $J=8.3 \mathrm{~Hz}, 2 \mathrm{H}, \mathrm{Ar}$ ), 7.70 $(\mathrm{d}, \mathrm{J}=8.3 \mathrm{~Hz}, 2 \mathrm{H}, \mathrm{Ar}), 6.28(\mathrm{~s}, 1 \mathrm{H}, \mathrm{CHOH}) \mathrm{ppm} .{ }^{13} \mathrm{C} \mathrm{NMR}(75 \mathrm{MHz}$, MeOD): $\delta=160.33\left(\mathrm{C}_{\mathrm{q}}\right), 147.05\left(\mathrm{C}_{\mathrm{q}}\right), 133.66\left(\mathrm{C}_{\mathrm{Ar}}\right), 128.44\left(\mathrm{C}_{\mathrm{Ar}}\right), 119.45$ $\left(\mathrm{C}_{\mathrm{q}}\right), 113.25\left(\mathrm{C}_{\mathrm{q}}\right), 67.75(\mathrm{CHOH}) \mathrm{ppm}$. IR: vmax $=3278,2231,1564$, $1405,1247,1056,796,569 \mathrm{~cm}^{-1}$. HRMS (TOF MSES positive mode) $\mathrm{m} / \mathrm{z}$ calcd. for $\mathrm{C}_{9} \mathrm{H}_{8} \mathrm{~N}_{5} \mathrm{O}[\mathrm{MH}]+$ : 202.0729; found : 202.0727.

(4'-Chloro-[1,1'-biphenyl]-4-yl)(1H-tetrazol-5-yl)methanol 3

White solid (87\%); Mp: $215-217^{\circ} \mathrm{C}$ (dec.); $\mathrm{Rf}=0.10(\mathrm{DCM} / \mathrm{MeOH} / \mathrm{AcOH}$ 96/2/2); ${ }^{1} \mathrm{H}$ NMR (300 MHz, MeOD): $\delta=7.56-7.40$ (m, $6 \mathrm{H}, \mathrm{Ar}$ ), 7.36-7.28 
(m, 2H, Ar), 6.09 (s, 1H, CHOH) ppm. ${ }^{13} \mathrm{C}$ NMR (75 MHz, MeOD): $\delta=$ $162.14\left(\mathrm{C}_{\mathrm{q}}\right), 141.75\left(\mathrm{C}_{\mathrm{q}}\right), 141.07\left(\mathrm{C}_{\mathrm{q}}\right), 140.59\left(\mathrm{C}_{\mathrm{q}}\right), 134.57\left(\mathrm{C}_{\mathrm{Ar}}\right), 129.96$ $\left(\mathrm{C}_{\mathrm{Ar}}\right), 129.50\left(\mathrm{C}_{\mathrm{Ar}}\right), 128.23\left(\mathrm{C}_{\mathrm{Ar}}\right), 128.11\left(\mathrm{C}_{\mathrm{Ar}}\right), 68.72(\mathrm{CHOH}) \mathrm{ppm}$. IR: $v \max =3354,1574,1485,1098,1054,791 \mathrm{~cm}^{-1}$. HRMS (TOF MSES positive mode) $\mathrm{m} / \mathrm{z}$ calcd. for $\mathrm{C}_{14} \mathrm{H}_{12} \mathrm{ClN}_{4} \mathrm{O}[\mathrm{MH}]+$ : 287.0700; found : 287.0696 .

\section{(1H-Tetrazol-5-yl)(p-tolyl)methanol 4}

White solid (98\%); Mp: $163-165^{\circ} \mathrm{C}$ (dec.); $\mathrm{Rf}=0.5(\mathrm{DCM} / \mathrm{MeOH} / \mathrm{AcOH}$ 96/4/2); ${ }^{1} \mathrm{H}$ NMR (300 MHz, MeOD): $\delta=7.21$ (d, $J=8.1 \mathrm{~Hz}, 2 \mathrm{H}, \mathrm{Ar}$ ), 7.08 (d, J = 8.0 Hz, 2H, Ar), $6.00(\mathrm{~s}, 1 \mathrm{H}, \mathrm{CHOH}), 2.21(\mathrm{~s}, 3 \mathrm{H}, \mathrm{Me}) \mathrm{ppm} .{ }^{13} \mathrm{C}$ NMR (75 MHz, MeOD): $\delta=161.00\left(\mathrm{C}_{\mathrm{q}}\right), 139.53\left(\mathrm{C}_{\mathrm{q}}\right), 138.72\left(\mathrm{C}_{\mathrm{q}}\right), 130.36$ $\left(\mathrm{C}_{\mathrm{Ar}}\right), 127.50\left(\mathrm{C}_{\mathrm{Ar}}\right), 68.48(\mathrm{CHOH}), 21.18(\mathrm{Me}) \mathrm{ppm}$. IR: vmax $=3405$ $1571,1513,1438,1115,1066,939,784,771,574,519 \mathrm{~cm}^{-1}$. HRMS (TOF MSES positive mode) $\mathrm{m} / \mathrm{z}$ calcd. for $\mathrm{C}_{9} \mathrm{H}_{11} \mathrm{~N}_{4} \mathrm{O}[\mathrm{MH}]+: 191.0933$ found : 191.0934 .

\section{1-(1H-Tetrazol-5-yl)octan-1-ol 5}

White solid (70\%); Mp: $116-118^{\circ} \mathrm{C} ; \mathrm{Rf}=0.2(\mathrm{DCM} / \mathrm{MeOH} / \mathrm{AcOH} 97 / 3 / 2)$ ${ }^{1} \mathrm{H}$ NMR (300 MHz, MeOD): $\delta=5.05(\mathrm{dd}, J=7.3,5.6 \mathrm{~Hz}, 1 \mathrm{H}, \mathrm{CHOH})$, $4.92(\mathrm{~s}, 1 \mathrm{H}, \mathrm{OH}), 2.00-1.78\left(\mathrm{~m}, 2 \mathrm{H}, \mathrm{CH}_{2} \mathrm{CHOH}\right), 1.50-1.23\left(\mathrm{~m}, 10 \mathrm{H}, \mathrm{CH}_{2}\right)$ 0.91 (t, $J=6.6 \mathrm{~Hz}, 3 \mathrm{H}, \mathrm{Me}) \mathrm{ppm} .{ }^{13} \mathrm{C}$ NMR $(75 \mathrm{MHz}, \mathrm{MeOD}): \delta=161.34$ $\left(\mathrm{C}_{\mathrm{q}}\right), 66.06(\boldsymbol{C H O H}), 37.64\left(\mathrm{CH}_{2}\right), 32.92\left(\mathrm{CH}_{2}\right), 30.32\left(\mathrm{CH}_{2}\right), 30.28\left(\boldsymbol{C H}_{2}\right)$ $25.90\left(\mathrm{CH}_{2}\right), 23.68\left(\mathrm{CH}_{2}\right), 14.41\left(\mathrm{CH}_{3}\right)$ ppm. IR: vmax $=3400,2921$ 2848, 1567, 1467, 1436, 1317, 1253, 1076, 1058, 952, 601, $534 \mathrm{~cm}^{-1}$ HRMS (TOF MSES positive mode) $\mathrm{m} / \mathrm{z}$ calcd. for $\mathrm{C}_{9} \mathrm{H}_{19} \mathrm{~N}_{4} \mathrm{O}[\mathrm{MH}]+$ 199.1559; found : 199.1559 .

\section{Ethyl benzyl(2-hydroxy-2-(1H-tetrazol-5-yl)ethyl)carbamate 6}

Sticky oil crystallizing on standing (83\%); $\mathrm{Mp}: 103-105^{\circ} \mathrm{C} ; \mathrm{Rf}=0.15$ (DCM/MeOH/AcOH 95/3/2); ${ }^{1} \mathrm{H}$ NMR (300 MHz, MeOD): $\delta=.27-7.08$ (m, $5 \mathrm{H}, \mathrm{Ph}), 5.21(\mathrm{~d}, J=5.8 \mathrm{~Hz}, 1 \mathrm{H}, \mathrm{CHOH}), 4.63-4.35\left(\mathrm{~m}, 2 \mathrm{H}, \mathrm{CH}_{2} \mathrm{Ph}\right)$, 4.10-3.82 (m, 2H, $\left.\mathrm{CH}_{2} \mathrm{CH}_{3}\right), 3.70-3.51(\mathrm{~m}, 1 \mathrm{H}, \mathrm{NCHHCHOH}), 3.51-3.32$ (m, $1 \mathrm{H}, \mathrm{NCH} \boldsymbol{H C H O H}), 1.07$ (dd, $\left.J=12.4,5.9 \mathrm{~Hz}, 3 \mathrm{H}, \mathrm{CH}_{2} \mathrm{CH}_{3}\right) . p p m .{ }^{13} \mathrm{C}$ NMR (75 MHz, MeOD): $\delta=159.53\left(\mathrm{C}_{\mathrm{q}}\right), 158.54$ and $158.37\left(\mathrm{C}_{\mathrm{q}}\right), 138.98$ and $138.80\left(\mathrm{C}_{\mathrm{q}}\right), 129.70\left(\mathrm{C}_{\mathrm{Ar}}\right), 128.76$ and $128.52\left(\mathrm{C}_{\mathrm{Ar}}\right), 128.36\left(\mathrm{C}_{\mathrm{Ar}}\right)$ 65.17 and $64.87(\mathrm{CHOH}), 63.07\left(\mathrm{CH}_{2} \mathrm{CH}_{3}\right), 52.88,52.6$ and 52.49 $\left(\mathrm{NCH}_{2} \mathrm{Ph}\right), 51.92\left(\mathrm{NCH}_{2} \mathrm{CHOH}\right), 14.74\left(\mathrm{CH}_{2} \mathrm{CH}_{3}\right)$ ppm. IR: vmax $=3420$ $1665,1420,1235,1112,1030,695 \mathrm{~cm}^{-1}$. HRMS (TOF MSES positive mode) $\mathrm{m} / \mathrm{z}$ calcd. for $\mathrm{C}_{13} \mathrm{H}_{18} \mathrm{~N}_{5} \mathrm{O}_{3}[\mathrm{MH}]+: 292.1410$; found : 292.1412

\section{[1-Benzyl-2-hydroxy-2-(2H-tetrazol-5-yl)-ethyl]-carbamic acid benzyl} ester 8

White solid (44\%); Mp: $158^{\circ} \mathrm{C}, \mathrm{Rf}=0.1(\mathrm{DCM} / \mathrm{MeOH} / \mathrm{AcOH}: 95 / 5 / 1) ;{ }^{1} \mathrm{H}$ NMR (300 MHz, CD $\left.{ }_{3} \mathrm{OD}\right): \delta=7.30-7.12(\mathrm{~m}, 5 \mathrm{H}, \mathrm{Ar}), 5.14(\mathrm{~d}, J=3.0 \mathrm{~Hz}$, $1 \mathrm{H}, \mathrm{CHOH}), 4.20-4.14(\mathrm{~m}, 1 \mathrm{H}, \mathrm{NCH}), 3.90\left(\mathrm{q}, J=6.9 \mathrm{~Hz}, 2 \mathrm{H}, \mathrm{OCH} \boldsymbol{H}_{2}\right.$, $3.08(\mathrm{dd}, J=13.5,6.6 \mathrm{~Hz}, 1 \mathrm{H}, \mathrm{PhCH} H), 2.81-2.74(\mathrm{~m}, 1 \mathrm{H}, \mathrm{PhCH}), 1.11$ (t, $J=6.9 \mathrm{~Hz}, 3 \mathrm{H}, \mathrm{Me}) \mathrm{ppm} .{ }^{13} \mathrm{C}$ NMR $\left(75 \mathrm{MHz}, \mathrm{CD}_{3} \mathrm{OD}\right): \delta=159.6\left(\mathrm{C}_{\mathrm{q}}\right)$, $158.4\left(\mathrm{C}_{\mathrm{q}}\right), 139.4\left(\mathrm{C}_{\mathrm{Ar}}\right), 130.3\left(\mathrm{C}_{\mathrm{Ar}}\right), 129.5\left(\mathrm{C}_{\mathrm{Ar}}\right), 127.5\left(\mathrm{C}_{\mathrm{Ar}}\right), 67.2$ $(\boldsymbol{C H O H}), 61.8\left(\mathrm{OCH}_{2}\right), 58.3(\boldsymbol{C H N}), 38.0\left(\mathrm{PhCH}_{2}\right), 14.8(\mathrm{Me}) \mathrm{ppm}$. IR : $v \max =3303,2983,1665,1547,1527,1443,1247,1049,775,751,699$ $\mathrm{cm}^{-1}$. HRMS (TOF MSES positive mode) $\mathrm{m} / \mathrm{z}$ calcd. For $\mathrm{C}_{13} \mathrm{H}_{18} \mathrm{~N}_{5} \mathrm{O}_{3}$ $[\mathrm{MH}]+$ : 292.1410; found : 292.1414.

\section{Ethyl benzyl(3-hydroxy-3-(1H-tetrazol-5-yl)propyl)carbamate 9}

Sticky oil (82\%); Rf= $0.3(\mathrm{DCM} / \mathrm{MeOH} / \mathrm{AcOH} 96 / 4 / 2) ;{ }^{1} \mathrm{H}$ NMR $(300 \mathrm{MHz}$ MeOD): $\delta=7.37-7.17(\mathrm{~m}, 5 \mathrm{H}, \mathrm{Ph}), 5.07$ (dd, $J=7.7,4.8 \mathrm{~Hz}, 1 \mathrm{H}, \mathrm{CHOH}$ ), $4.50\left(\mathrm{~s}, 2 \mathrm{H}, \mathrm{NCH}_{2} \mathrm{Ph}\right), 4.16\left(\mathrm{q}, \mathrm{J}=7.1 \mathrm{~Hz}, 2 \mathrm{H}, \mathrm{CH}_{2} \mathrm{CH}_{3}\right), 3.60-3.27(\mathrm{~m}$, $\left.2 \mathrm{H}, \mathrm{NCH}_{2} \mathrm{CH}_{2}\right), 2.30-1.97\left(\mathrm{~m}, 2 \mathrm{H}, \mathrm{NCH}_{2} \mathrm{CH}_{2}\right), 1.25(\mathrm{t}, \mathrm{J}=6.7 \mathrm{~Hz}, 3 \mathrm{H}$ $\left.\mathrm{CH}_{2} \mathrm{CH}_{3}\right) \mathrm{ppm} .{ }^{13} \mathrm{C}$ NMR $(75 \mathrm{MHz}, \mathrm{MeOD}): \delta=161.02\left(\mathrm{C}_{\mathrm{q}}\right), 158.50\left(\mathrm{C}_{\mathrm{q}}\right)$, $139.13\left(\mathrm{C}_{\mathrm{q}}\right), 129.69\left(\mathrm{C}_{\mathrm{Ar}}\right), 128.75\left(\mathrm{C}_{\mathrm{Ar}}\right), 128.51\left(\mathrm{C}_{\mathrm{Ar}}\right), 64.09(\mathrm{CHOH})$, $62.97\left(\mathrm{CH}_{2} \mathrm{CH}_{3}\right), 51.49\left(\mathrm{NCH}_{2} \mathrm{Ph}\right), 44.31$ and $43.74\left(\mathrm{NCH}_{2} \mathrm{CH}_{2}\right), 35.94$ and $35.47\left(\mathrm{NCH}_{2} \mathrm{CH}_{2}\right), 14.99\left(\mathrm{CH}_{2} \mathrm{CH}_{3}\right)$ ppm. IR: vmax = 3344, 2983 1654, 1424, 1240, 1092, $698 \mathrm{~cm}^{-1}$. HRMS (TOF MSES positive mode) $\mathrm{m} / \mathrm{z}$ calcd. for $\mathrm{C}_{16} \mathrm{H}_{24} \mathrm{~N}_{5} \mathrm{O}_{3}[\mathrm{MH}]+$ : 306.1566 ; found : 306.1565 .

\section{Ethyl benzyl(5-hydroxy-5-(1H-tetrazol-5-yl)pentyl)carbamate 10}

White solid (86\%); $\mathrm{Mp}: 95-97^{\circ} \mathrm{C} ; \mathrm{Rf}=0.3(\mathrm{DCM} / \mathrm{MeOH} / \mathrm{AcOH} 97 / 3 / 2) ;{ }^{1} \mathrm{H}$ NMR (300 MHz, MeOD): $\delta=7.37-7.19(\mathrm{~m}, 5 \mathrm{H}, \mathrm{Ph}), 5.03$ (dd, $J=7.2,5.6$ $\mathrm{Hz}, 1 \mathrm{H}, \mathrm{CHOH}), 4.49$ (s, 2H, NCH$\left.{ }_{2} \mathrm{Ph}\right), 4.16\left(\mathrm{q}, J=6.8 \mathrm{~Hz}, 2 \mathrm{H}, \mathrm{CH}_{2} \mathrm{CH}_{3}\right.$ ), 3.33-3.16 (m, 2H, NCH $\left.\mathrm{CH}_{2}\right), 2.98-1.76\left(\mathrm{~m}, 2 \mathrm{H}, \mathrm{CH}_{2}\right), 1.65-1.47(\mathrm{~m}, 2 \mathrm{H}$, $\left.\mathrm{CH}_{2}\right), 1.45-1.17\left(\mathrm{~m}, 5 \mathrm{H}, \mathrm{CH}_{2}\right.$ and $\left.\mathrm{CH}_{2} \mathrm{CH}_{3}\right)$ ppm. ${ }^{13} \mathrm{C} \mathrm{NMR}(75 \mathrm{MHz}$, MeOD): $\delta=161.27\left(\mathrm{C}_{\mathrm{q}}\right), 158.73\left(\mathrm{C}_{\mathrm{q}}\right), 139.36\left(\mathrm{C}_{\mathrm{q}}\right), 129.62\left(\mathrm{C}_{\mathrm{Ar}}\right), 128.70$ $\left(\mathrm{C}_{\mathrm{Ar}}\right), 128.41\left(\mathrm{C}_{\mathrm{Ar}}\right), 65.93(\mathrm{CHOH}), 62.79\left(\mathrm{CH}_{2} \mathrm{CH}_{3}\right), 51.26\left(\mathrm{NCH}_{2} \mathrm{Ph}\right)$, 47.90 and $47.31\left(\mathrm{NCH}_{2} \mathrm{CH}_{2}\right), 37.22\left(\mathrm{CH}_{2}\right), 28.79$ and $28.39\left(\mathrm{CH}_{2}\right), 23.10$ $\left(\mathrm{CH}_{2}\right), 15.00\left(\mathrm{CH}_{2} \mathrm{CH}_{3}\right)$ ppm. IR: vmax = 3341, 2925, 1664, 1431, 1249 $1095,695 \mathrm{~cm}^{-1}$. HRMS (TOF MSES positive mode) $\mathrm{m} / \mathrm{z}$ calcd. for $\mathrm{C}_{16} \mathrm{H}_{24} \mathrm{~N}_{5} \mathrm{O}_{3}[\mathrm{MH}]+$ : 334.1875 ; found : 334.1879.

\section{Benzyl benzyl(2-hydroxy-2-(1H-tetrazol-5-yl)ethyl)carbamate 11}

White solid (85\%); Mp: 157-159 ${ }^{\circ} \mathrm{C} ; \mathrm{Rf}=0.35(\mathrm{DCM} / \mathrm{MeOH} / \mathrm{AcOH} 95 / 3 / 2)$; 1H NMR (300 MHz, MeOD): $\delta=7.29-7.02(\mathrm{~m}, 10 \mathrm{H}, \mathrm{Ph}), 5.33-5.12(\mathrm{~m}$ $1 \mathrm{H}, \mathrm{CHOH}$ ), 4.96 and 5.00 (two s, 2H, Cbz), 4.65-4.36 (m, 2H, NCH $\mathrm{H}_{2} \mathrm{Ph}$ ), $3.65(\mathrm{td}, J=14.5,5.0 \mathrm{~Hz}, 1 \mathrm{H}, \mathrm{NCHHCHOH}), 3.55-3.33(\mathrm{~m}, 1 \mathrm{H}$, $\mathrm{NCH} H \mathrm{CHOH}) \mathrm{ppm} .{ }^{13} \mathrm{C}$ NMR $(75 \mathrm{MHz}, \mathrm{MeOD}): \delta=159.46\left(\mathrm{C}_{\mathrm{q}}\right), 158.29$ $\left(\mathrm{C}_{\mathrm{q}}\right), 138.90$ and $138.63\left(\mathrm{C}_{\mathrm{q}}\right), 137.78\left(\mathrm{C}_{\mathrm{q}}\right), 129.71\left(\mathrm{C}_{\mathrm{Ar}}\right), 129.54\left(\mathrm{C}_{\mathrm{Ar}}\right)$ $129.17\left(\mathrm{C}_{\mathrm{Ar}}\right), 129.00\left(\mathrm{C}_{\mathrm{Ar}}\right), 128.74$ and $128.55\left(\mathrm{C}_{\mathrm{Ar}}\right), 128.48$ and 128.33 $\left(\mathrm{C}_{\mathrm{Ar}}\right), 68.72$ and $68.65(\mathrm{Cbz}), 65.22$ and $64.86(\mathrm{CHOH}), 53.19$ and 52.85 $\left(\mathrm{NCH}_{2} \mathrm{Ph}\right), 52.67$ and $52.06\left(\mathrm{NCH}_{2} \mathrm{CHOH}\right) \mathrm{ppm}$. IR: vmax $=3401,3059$, $3027,2518,1678,1426,1237,728,700 \mathrm{~cm}^{-1}$. HRMS (TOF MSES positive mode) $\mathrm{m} / \mathrm{z}$ calcd. for $\mathrm{C}_{18} \mathrm{H}_{20} \mathrm{~N}_{5} \mathrm{O}_{3}[\mathrm{MH}]+$ : 354.1566; found : 354.1566 .

\section{Benzyl benzyl(3-hydroxy-3-(1H-tetrazol-5-yl)propyl)carbamate 12}

White solid (81\%); Mp: $134-136^{\circ} \mathrm{C} ; \mathrm{Rf}=0.5(\mathrm{DCM} / \mathrm{MeOH} / \mathrm{AcOH}$ 97/3/2); ${ }^{1} \mathrm{H}$ NMR $(300 \mathrm{MHz}, \mathrm{MeOD}): \delta=7.45-7.10(\mathrm{~m}, 10 \mathrm{H}, \mathrm{Ph}), 5.16(\mathrm{~s}, 2 \mathrm{H}$, $\left.\mathrm{OCH}_{2} \mathrm{Ph}\right), 5.10-5.00(\mathrm{~m}, 1 \mathrm{H}, \mathrm{CHOH}), 4.52\left(\mathrm{~s}, 2 \mathrm{H}, \mathrm{NCH}_{2} \mathrm{Ph}\right), 3.63-3.35(\mathrm{~m}$, $\left.2 \mathrm{H}, \mathrm{NCH}_{2} \mathrm{CH}_{2}\right), 2.30-1.98\left(\mathrm{~m}, 2 \mathrm{H}, \mathrm{NCH}_{2} \mathrm{CH}_{2}\right)$ ppm. ${ }^{13} \mathrm{C} \mathrm{NMR}(75 \mathrm{MHz}$, MeOD): $\delta=161.05\left(\mathrm{C}_{\mathrm{q}}\right), 158.19\left(\mathrm{C}_{\mathrm{q}}\right), 139.02\left(\mathrm{C}_{\mathrm{q}}\right), 137.98\left(\mathrm{C}_{\mathrm{q}}\right), 129.69$ $\left(\mathrm{C}_{\mathrm{Ar}}\right), 129.57\left(\mathrm{C}_{\mathrm{Ar}}\right), 129.15\left(\mathrm{C}_{\mathrm{Ar}}\right), 128.96\left(\mathrm{C}_{\mathrm{Ar}}\right), 128.75\left(\mathrm{C}_{\mathrm{Ar}}\right), 128.51\left(\mathrm{C}_{\mathrm{Ar}}\right)$, $68.57\left(\mathrm{OCH}_{2} \mathrm{Ph}\right), 64.08(\mathrm{CHOH}), 51.63\left(\mathrm{NCH}_{2} \mathrm{Ph}\right), 44.64$ and 43.85 $\left(\mathrm{NCH}_{2} \mathrm{CH}_{2}\right), 36.07$ and $35.48\left(\mathrm{NCH}_{2} \mathrm{CH}_{2}\right)$ ppm. IR: vmax $=3381,1668$ 1434, 1231, 1022, 735, $695 \mathrm{~cm}^{-1}$. HRMS (TOF MSES positive mode) $\mathrm{m} / \mathrm{z}$ calcd. for $\mathrm{C}_{19} \mathrm{H}_{22} \mathrm{~N}_{5} \mathrm{O}_{3}[\mathrm{MH}]+:$ : 368.1723; found : 368.1729 .

\section{Ethyl (2-hydroxy-2-(1H-tetrazol-5-yl)ethyl)carbamate 13}

White foam (56\%); Rf= $0.2(\mathrm{DCM} / \mathrm{MeOH} / \mathrm{AcOH} 96 / 4 / 2) ;{ }^{1} \mathrm{H}$ NMR $(300$ $\mathrm{MHz}, \mathrm{MeOD}$ ): $\delta=5.03(\mathrm{t}, J=5.7 \mathrm{~Hz}, 1 \mathrm{H}, \mathrm{CHOH}), 3.94(\mathrm{q}, J=7.1 \mathrm{~Hz}, 2 \mathrm{H}$, $\mathrm{CH}_{2} \mathrm{CH}_{3}$ ), 3.48 (dd, $J=14.1,5.2 \mathrm{~Hz}, 1 \mathrm{H}, \mathrm{NHCHH}$ ), 3.38 (dd, $J=14.1,6.8$ $\mathrm{Hz}, 1 \mathrm{H}, \mathrm{NHCH} \boldsymbol{H}), 1.10\left(\mathrm{t}, \boldsymbol{J}=7.1 \mathrm{~Hz}, 3 \mathrm{H}, \mathrm{CH}_{2} \mathrm{CH}_{3}\right) \mathrm{ppm} .{ }^{13} \mathrm{C}$ NMR $(75$ $\mathrm{MHz}, \mathrm{MeOD}): \delta=160.30\left(\mathrm{C}_{\mathrm{q}}\right), 159.29\left(\mathrm{C}_{\mathrm{q}}\right), 65.91(\mathrm{CHOH}), 61.97$ $\left(\mathrm{CH}_{2} \mathrm{CH}_{3}\right), 46.97\left(\mathrm{NHCH}_{2}\right), 14.93\left(\mathrm{CH}_{2} \mathrm{CH}_{3}\right)$ ppm. IR: vmax = 3354, 2929, 1667, 1454, 1250, 1093, 1030, 774, $695 \mathrm{~cm}^{-1}$. HRMS (TOF MSES positive mode) $\mathrm{m} / \mathrm{z}$ calcd. for $\mathrm{C}_{6} \mathrm{H}_{12} \mathrm{~N}_{5} \mathrm{O}_{3}[\mathrm{MH}]+$ : 202.0940; found : 202.0941 .

\section{2-(Dibenzylamino)-1-(1H-tetrazol-5-yl)ethanol 14}

Sticky oil (87\%); $\mathrm{Rf}=0.1(\mathrm{DCM} / \mathrm{MeOH} / \mathrm{AcOH} 95 / 3 / 2) ;{ }^{1} \mathrm{H}$ NMR $(300 \mathrm{MHz}$, MeOD): $\delta=7.26-7.13(\mathrm{~m}, 10 \mathrm{H}, \mathrm{Ph}), 5.14(\mathrm{t}, J=6.4 \mathrm{~Hz}, 1 \mathrm{H}, \mathrm{CHOH}), 3.80$ (s, 4H, NCH$\left.H_{2} \mathrm{Ph}\right), 3.07-2.92(\mathrm{~m}, 2 \mathrm{H}, \mathrm{NCH} 2 \mathrm{CH}) \mathrm{ppm} .{ }^{13} \mathrm{C} \mathrm{NMR}(75 \mathrm{MHz}$ MeOD): $\delta=161.35\left(\mathrm{C}_{\mathrm{q}}\right), 137.50\left(\mathrm{C}_{\mathrm{q}}\right), 130.69\left(\mathrm{C}_{\mathrm{Ar}}\right), 129.64\left(\mathrm{C}_{\mathrm{Ar}}\right), 129.02$ $\left(\mathrm{C}_{\mathrm{Ar}}\right), 64.16(\mathrm{CHOH}), 59.66\left(\mathrm{NCH}_{2} \mathrm{Ph}\right), 59.02\left(\mathrm{NCH}_{2} \mathrm{CH}\right) \mathrm{ppm}$. IR: vmax = $3110,1457,735,696 \mathrm{~cm}^{-1}$. HRMS (TOF MSES positive mode) $\mathrm{m} / \mathrm{z}$ calcd. for $\mathrm{C}_{17} \mathrm{H}_{20} \mathrm{~N}_{5} \mathrm{O}[\mathrm{MH}]+$ : 310.1668 ; found : 310.1664 .

\section{3-(Dibenzylamino)-1-(1H-tetrazol-5-yl)propan-1-ol 15}

Sticky oil (81\%); $\mathrm{Rf}=0.25\left(\mathrm{DCM} / \mathrm{MeOH} / \mathrm{AcOH}\right.$ 90/10/2); ${ }^{1} \mathrm{H}$ NMR $(300$ $\mathrm{MHz}, \mathrm{MeOD}): \delta=7.32-7.15(\mathrm{~m}, 10 \mathrm{H}, \mathrm{Ph}), 4.92(\mathrm{t}, J=5.8 \mathrm{~Hz}, 1 \mathrm{H}, \mathrm{CHOH})$, 3.95 and 3.79 (two d, $J=13.4 \mathrm{~Hz}, 4 \mathrm{H}$ ), 3.08-2.93 (m, $1 \mathrm{H}, \mathrm{NCH} \mathrm{HCH}_{2}$ ), 2.90-2.75 (m, $\left.1 \mathrm{H}, \mathrm{NCH} \boldsymbol{H C H}_{2}\right), 2.30-2.03\left(\mathrm{~m}, 2 \mathrm{H}, \mathrm{NCH}_{2} \mathrm{CH}_{2}\right)$ ppm. ${ }^{13} \mathrm{C}$ NMR (75 MHz, MeOD): $\delta=164.43\left(\mathrm{C}_{\mathrm{q}}\right), 135.38\left(\mathrm{C}_{\mathrm{q}}\right), 131.17\left(\mathrm{C}_{\mathrm{Ar}}\right)$, 
$129.94\left(\mathrm{C}_{\mathrm{Ar}}\right), 129.67\left(\mathrm{C}_{\mathrm{Ar}}\right), 66.20(\mathrm{CHOH}), 58.71\left(\mathrm{NCH}_{2} \mathrm{Ph}\right), 51.13$ $\left(\mathrm{NCH}_{2} \mathrm{CH}_{2}\right)$, $32.57\left(\mathrm{NCH}_{2} \mathrm{CH}_{2}\right)$ ppm. IR: vmax $=3097,1454,1068,1026$, 732, $695 \mathrm{~cm}^{-1}$. HRMS (TOF MSES positive mode) $\mathrm{m} / \mathrm{z}$ calcd. for $\mathrm{C}_{18} \mathrm{H}_{22} \mathrm{~N}_{5} \mathrm{O}[\mathrm{MH}]+$ : 324.1824 ; found : 324.1825 .

\section{1-(1H-Tetrazol-5-yl)-4-(trityloxy)butan-1-ol 16}

White solid (75\%); Mp: $152-154^{\circ} \mathrm{C} ; \quad \mathrm{Rf}=0.4 \quad(\mathrm{DCM} / \mathrm{MeOH} / \mathrm{AcOH}$ 99.5/0.5/2); ${ }^{1} \mathrm{H}$ NMR (300 MHz, MeOD): $\delta=7.49-7.36(\mathrm{~m}, 6 \mathrm{H}, \mathrm{Ar}), 7.36$ - $7.06(\mathrm{~m}, 9 \mathrm{H}, \mathrm{Ar}), 5.04$ (dd, $J=7.6,5.2 \mathrm{~Hz}, 1 \mathrm{H}, \mathrm{CHOH}), 3.14$ (t, $J=6.3$ $\left.\mathrm{Hz}, 2 \mathrm{H}, \mathrm{CH}_{2} \mathrm{OTr}\right), 2.17-1.85\left(\mathrm{~m}, 2 \mathrm{H}, \mathrm{CH}_{2}\right), 1.80-1.62\left(\mathrm{~m}, 2 \mathrm{H}, \mathrm{CH}_{2}\right.$ ppm. ${ }^{13} \mathrm{C}$ NMR $(75 \mathrm{MHz}, \mathrm{MeOD}): \delta=161.23\left(\mathrm{C}_{\mathrm{q}}\right), 145.69\left(\mathrm{C}_{\mathrm{q}}\right), 129.80$ $\left(\mathrm{C}_{\mathrm{Ar}}\right), 128.76\left(\mathrm{C}_{\mathrm{Ar}}\right), 128.03\left(\mathrm{C}_{\mathrm{Ar}}\right), 87.82\left(\mathrm{C}_{\mathrm{q}}\right), 65.92(\mathrm{CHOH}), 64.13\left(\mathrm{CH}_{2}\right)$ $34.66\left(\mathrm{CH}_{2}\right), 26.52\left(\mathrm{CH}_{2}\right)$ ppm. IR: vmax $=3401,1590,1488,1446,1257$ $1072,752,701,636 \mathrm{~cm}^{-1}$. HRMS (TOF MSES negative mode) $\mathrm{m} / \mathrm{z}$ calcd. for $\mathrm{C}_{24} \mathrm{H}_{22} \mathrm{~N}_{4} \mathrm{O}_{2}\left[\mathrm{M}-\mathrm{H}^{+}\right]$: 399.1811 ; found : 399.1811

\section{Benzyl benzyl(2-((ethoxycarbonyl)oxy)-2-(1H-tetrazol-5- yl)ethyl)carbamate 24}

Sticky oil (88\%); $\mathrm{Rf}=0.3(\mathrm{DCM} / \mathrm{MeOH} / \mathrm{AcOH} 96 / 2 / 2) ;{ }^{1} \mathrm{H} \mathrm{NMR}(300 \mathrm{MHz}$, MeOD): $\delta=7.32-6.98(\mathrm{~m}, 10 \mathrm{H}, \mathrm{Ph}), 6.22-6.04\left(\mathrm{~m}, 1 \mathrm{H}, \mathrm{NCH}_{2} \mathrm{CHTet}\right)$, 4.99 (s, 2H, Cbz), 4.55-4.33 (m, 2H, NCH $\left.H_{2} \mathrm{Ph}\right), 4.05$ (q, J = 7.1 Hz, 2H, $\mathrm{OCH}_{2} \mathrm{CH}_{3}$ ), 3.85-3.69 (s, 2H, NCH $\mathrm{CHTet}_{2}, 1.14(\mathrm{t}, \mathrm{J}=7.1 \mathrm{~Hz}, 3 \mathrm{H}$ $\mathrm{OCH}_{2} \mathrm{CH}_{3}$ ) ppm. ${ }^{13} \mathrm{C}$ NMR $(75 \mathrm{MHz}, \mathrm{MeOD}): \delta=158.04\left(\mathrm{C}_{\mathrm{q}}\right), 156.79$ and $156.55\left(\mathrm{C}_{\mathrm{q}}\right), 155.44\left(\mathrm{C}_{\mathrm{q}}\right), 138.64$ and $138.39\left(\mathrm{C}_{\mathrm{q}}\right), 137.66\left(\mathrm{C}_{\mathrm{q}}\right), 129.77$ $\left(\mathrm{C}_{\mathrm{Ar}}\right), 128.69\left(\mathrm{C}_{\mathrm{Ar}}\right), 128.60\left(\mathrm{C}_{\mathrm{Ar}}\right), 129.57\left(\mathrm{C}_{\mathrm{Ar}}\right), 129.22\left(\mathrm{C}_{\mathrm{Ar}}\right), 129.02\left(\mathrm{C}_{\mathrm{Ar}}\right)$, $128.77\left(\mathrm{C}_{\mathrm{Ar}}\right), 128.35\left(\mathrm{C}_{\mathrm{Arr}}\right), 69.86$ and $69.58\left(\mathrm{CHOCO}_{2} \mathrm{Et}\right), 69.00$ and $68.79(\mathrm{Cbz}), 66.11\left(\mathrm{OCH}_{2} \mathrm{Me}\right), 52.80$ and $52.56\left(\mathrm{NCH}_{2} \mathrm{Ph}\right), 50.77$ and $49.76\left(\mathrm{NCH}_{2} \mathrm{CHTet}\right), 14.50$ (Me) ppm. IR: vmax $=2960,1750,1670$, 1247, 1125, 1021, 733, $696 \mathrm{~cm}^{-1}$. HRMS (TOF MSES positive mode) $\mathrm{m} / \mathrm{z}$ calcd. for $\mathrm{C}_{21} \mathrm{H}_{24} \mathrm{~N}_{5} \mathrm{O}_{5}[\mathrm{MH}]+:$ : 426.1781 ; found : 426.1791 .

\section{General procedure for the activation of AHT}

$D I C$ and EDC

In a dried round-bottomed flask under argon atmosphere was added DIC or EDC (1.2 eq.) to a suspension of $\mathrm{AHT}$ in distilled DCM at room temperature. The reaction mixture was allowed to stir at room temparture for 24 hours. The solvent was then removed and the residue was purified by flash chromatography on silica gel with a mixture of PE/EtOAc.

\section{DAST}

In a dried round-bottomed flask under argon atmosphere, DIPEA (1.0 eq.) was added to a suspension of $\mathrm{AHT}$ in distilled $\mathrm{DCM}$ at $0^{\circ} \mathrm{C}$. After complete dissolution, DAST (1.5 eq.) was added at $0^{\circ} \mathrm{C}$. The reaction mixture was allowed to stir at room temparture for 20 minutes and methanol was then added $(1 \mathrm{~mL} / \mathrm{mmol})$. The solvent was then removed and the residue was purified by flash chromatography on silica gel with a mixture of PE/EtOAc.

\section{Thionyl chloride}

In a dried round-bottomed flask under argon atmosphere DIPEA (1.0 eq.) was added to a suspension of AHT in distilled DCM. After complete dissolution, $\mathrm{SOCl}_{2}$ (2 eq.) was added at room temperature. The reaction mixture was allowed to stir at room temparture for 24 hours, then quenched with satured aqueous $\mathrm{NaHCO}_{3}$ and extracted with DCM. The combined organic layers were dried over $\mathrm{MgSO}_{4}$, evaporated and the residue purified by flash chromatography on silica gel with a mixture of a $\mathrm{DCM} / \mathrm{MeOH} / \mathrm{AcOH}$ mixture.

\section{Ethyl benzyl(prop-2-yn-1-yl)carbamate 6a}

Colorless oil $(70 \%) ; \mathrm{Rf}=0.4$ (PE/EtOAc: $90 / 10) ;{ }^{1} \mathrm{H}$ NMR $(300 \mathrm{MHz}$, $\left.\mathrm{CDCl}_{3}\right): \delta=7.30-7.14(\mathrm{~m}, 5 \mathrm{H}, \mathrm{Ph}), 4.53\left(\mathrm{~s}, 2 \mathrm{H}, \mathrm{NCH}_{2} \mathrm{Ph}\right), 4.15$ (q, $J=7.1$ $\left.\mathrm{Hz}, 2 \mathrm{H}, \mathrm{CH}_{2} \mathrm{CH}_{3}\right), 4.05-3.80\left(\mathrm{~m}, 2 \mathrm{H}, \mathrm{NCH}_{2} \mathrm{CCH}\right), 2.15(\mathrm{t}, J=2.4 \mathrm{~Hz}, 1 \mathrm{H}$ $\mathrm{CCH}), 1.21$ (t, $\left.J=7.1 \mathrm{~Hz}, 3 \mathrm{H}, \mathrm{CH}_{2} \mathrm{CH}_{3}\right) \mathrm{ppm} .{ }^{13} \mathrm{C} \mathrm{NMR}\left(75 \mathrm{MHz}, \mathrm{CDCl}_{3}\right)$ : $\delta=156.04\left(\mathrm{C}_{\mathrm{q}}\right), 136.99\left(\mathrm{C}_{\mathrm{q}}\right), 128.62\left(\mathrm{C}_{\mathrm{Ar}}\right), 128.2$ and $127.81\left(\mathrm{C}_{\mathrm{Ar}}\right)$, $127.58\left(\mathrm{C}_{\mathrm{Ar}}\right), 78.99(\mathrm{CCH}), \quad 72.00(\mathrm{CCH}), 61.99\left(\mathrm{CH}_{2} \mathrm{CH}_{3}\right), \quad 49.14$
$\left(\mathrm{NCH}_{2} \mathrm{Ph}\right), 35.36\left(\mathrm{NCH}_{2} \mathrm{CCH}\right), 14.67\left(\mathrm{CH}_{2} \mathrm{CH}_{3}\right)$ ppm. IR: vmax = 3287, 3246, 2986, 1692, 1415, 1231, 1114, 1017, $697 \mathrm{~cm}^{-1}$. HRMS (TOF MSES positive mode) $\mathrm{m} / \mathrm{z}$ calcd. for $\mathrm{C}_{13} \mathrm{H}_{16} \mathrm{NO}[\mathrm{MH}]+: 218.1181$; found 218.1174

\section{(1-Benzyl-prop-2-ynyl)-carbamic acid ethyl ester 8a}

Colorless oil (59\%); Rf : 0.7 (DCM/MeOH/AcOH : 89/10/1) ; ${ }^{1} \mathrm{H}$ NMR (300 $\left.\mathrm{MHz}, \mathrm{CDCl}_{3}\right): \delta=7.27-7.16(\mathrm{~m}, 5 \mathrm{H}, \mathrm{Ar}), 4.76$ (bs, $1 \mathrm{H}, \mathrm{NHCO}$ ), 4.66 (bs, $1 \mathrm{H}, \mathrm{NCH}), 4.00\left(\mathrm{q}, J=7.2 \mathrm{~Hz}, 2 \mathrm{H}, \mathrm{OCH}{ }_{2}\right), 2.98-2.84\left(\mathrm{~m}, 2 \mathrm{H}, \mathrm{PhCH}_{2}\right)$, $2.22(\mathrm{~d}, J=2.4 \mathrm{~Hz}, 1 \mathrm{H}, \mathrm{C} \equiv \mathrm{CH}), 1.15(\mathrm{t}, J=7.2 \mathrm{~Hz}, 3 \mathrm{H}, \mathrm{Me}) \mathrm{ppm} .{ }^{13} \mathrm{C}$ NMR $\left(75 \mathrm{MHz}, \mathrm{CDCl}_{3}\right): \delta=155.4\left(\mathrm{C}_{\mathrm{q}}\right), 136.1\left(\mathrm{C}_{\mathrm{q}}\right), 129.8\left(\mathrm{C}_{\mathrm{Ar}}\right), 128.3$ $\left(\mathrm{C}_{\mathrm{Ar}}\right), 127.0\left(\mathrm{C}_{\mathrm{Ar}}\right), 82.5(\mathrm{C} \equiv \mathrm{CH}), 72.4(\mathrm{C} \equiv \mathrm{CH}), 61.2\left(\mathrm{OCH}_{2}\right), 44.2(\mathrm{CHN})$, $41.6\left(\mathrm{PhCH}_{2}\right), 14.6(\mathrm{Me}) \mathrm{ppm}$. IR : vmax $=3294,3030,2980,2942$ $1691,1521,1495,1332,1239,1038,749,698,644 \mathrm{~cm}^{-1}$. HRMS (TOF MSES positive mode) $\mathrm{m} / z$ calcd. for $\mathrm{C}_{13} \mathrm{H}_{16} \mathrm{NO}_{2}[\mathrm{MH}]+: 218.1181$; found : 218.1173.=

\section{Ethyl benzyl(but-3-yn-1-yl)carbamate 9a}

Colorless oil (43\%); Rf= 0.45 (PE/EtOAc: $90 / 10) ;{ }^{1} \mathrm{H}$ NMR $(300 \mathrm{MHz}$ $\left.\mathrm{CDCl}_{3}\right): \delta=7.48-7.12(\mathrm{~m}, 5 \mathrm{H}, \mathrm{Ph}), 4.61\left(\mathrm{~s}, 2 \mathrm{H}, \mathrm{NCH}_{2} \mathrm{Ph}\right), 4.32-4.15(\mathrm{~m}$ $\left.2 \mathrm{H}, \mathrm{CH}_{2} \mathrm{CH}_{3}\right)$, 3.55-3.33 (m, 2H, $\left.\mathrm{NCH}_{2} \mathrm{CH}_{2}\right), 2.55-2.32\left(\mathrm{~m}, 2 \mathrm{H}, \mathrm{NCH}_{2} \mathrm{CH}_{2}\right)$, $2.01(\mathrm{t}, J=2.6 \mathrm{~Hz}, 1 \mathrm{H}, \mathrm{CCH}), 1.43-1.22\left(\mathrm{~m}, 3 \mathrm{H}, \mathrm{CH}_{2} \mathrm{CH}_{3}\right) \mathrm{ppm} .{ }^{13} \mathrm{C} \mathrm{NMR}$ $\left(75 \mathrm{MHz}, \mathrm{CDCl}_{3}\right): \delta=156.6$ and $156.30\left(\mathrm{C}_{\mathrm{\sigma}}\right), 137.84\left(\mathrm{C}_{\circ}\right), 128.62\left(\mathrm{C}_{\mathrm{Ar}}\right)$, $127.90\left(\mathrm{C}_{\mathrm{Ar}}\right), 127.43\left(\mathrm{C}_{\mathrm{Ar}}\right), 81.89$ and $81.55(\mathrm{CCH}), 69.75(\mathrm{CCH}), 61.60$ $\left(\mathrm{CH}_{2} \mathrm{CH}_{3}\right), 51.01\left(\mathrm{NCH}_{2} \mathrm{Ph}\right), 45.96$ and $45.13\left(\mathrm{NCH}_{2} \mathrm{CH}_{2}\right), 18.31$ and $17.94\left(\mathrm{NCH}_{2} \mathrm{CH}_{2}\right), 14.70\left(\mathrm{CH}_{2} \mathrm{CH}_{3}\right)$ ppm. IR: vmax $=3294,2976,1690$ 1418, 1236, 1212, 1116, 698, $635 \mathrm{~cm}^{-1}$. HRMS (TOF MSES positive mode) $\mathrm{m} / \mathrm{z}$ calcd. for $\mathrm{C}_{13} \mathrm{H}_{16} \mathrm{NO}[\mathrm{MH}]+: 232.1338$; found : 232.1335 .

\section{Ethyl benzyl(hex-5-yn-1-yl)carbamate 10a}

Colorless oil (44\%); Rf $=0.55$ (PE/EtOAc: $90 / 10) ;{ }^{1} \mathrm{H}$ NMR $(300 \mathrm{MHz}$ $\left.\mathrm{CDCl}_{3}\right): \delta=7.48-7.12(\mathrm{~m}, 5 \mathrm{H}, \mathrm{Ph}), 4.52\left(\mathrm{~s}, 2 \mathrm{H}, \mathrm{NCH}_{2} \mathrm{Ph}\right), 4.22$ (q, $J=7.0$ $\left.\mathrm{Hz}, 2 \mathrm{H}, \mathrm{CH}_{2} \mathrm{CH}_{3}\right), 3.37-3.15\left(\mathrm{~m}, 2 \mathrm{H} \mathrm{NCH} \mathrm{CH}_{2}\right), 2.22$ (td, $\mathrm{J}=6.8,2.4 \mathrm{~Hz}$, $\left.2 \mathrm{H}, \mathrm{CH}_{2} \mathrm{CCH}\right), 1.98(\mathrm{t}, \boldsymbol{J}=2.6 \mathrm{~Hz}, 1 \mathrm{H}, \mathrm{CCH}), 1.75-1.60\left(\mathrm{~m}, 2 \mathrm{H}, \mathrm{CH}_{2}\right)$, 1.60-1.43 (m, 2H, CH $\left.\boldsymbol{H}_{2}\right), 1.40-1.20\left(\mathrm{~m}, 3 \mathrm{H}, \mathrm{CH}_{2} \mathrm{CH}_{3}\right) \mathrm{ppm} .{ }^{13} \mathrm{C} \mathrm{NMR}(75$ $\left.\mathrm{MHz}, \mathrm{CDCl}_{3}\right): \delta=156.97$ and $156.58\left(\mathrm{C}_{\mathrm{q}}\right), 138.05\left(\mathrm{C}_{\mathrm{q}}\right), 128.54\left(\mathrm{C}_{\mathrm{Ar}_{\mathrm{r}}}\right)$ 127.86 $\left(\mathrm{C}_{\mathrm{Ar}}\right), 127.29\left(\mathrm{C}_{\mathrm{Ar}}\right), 84.08(\mathrm{CCH}), 68.58(\mathrm{CCH}), 61.40\left(\mathrm{CH}_{2} \mathrm{CH}_{3}\right)$, 50.18 and $49.99\left(\mathrm{NCH}_{2} \mathrm{Ph}\right), 46.15$ and $45.44\left(\mathrm{NCH}_{2} \mathrm{CH}_{2}\right), 27.00$ and $26.82\left(\mathrm{CH}_{2}\right), 25.58\left(\mathrm{CH}_{2}\right), 18.13\left(\mathrm{CH}_{2}\right), 14.72\left(\mathrm{CH}_{2} \mathrm{CH}_{3}\right)$ ppm. IR: vmax $=$ $3297,3252,2926,1689,1421,1229,1117,698,630 \mathrm{~cm}^{-1}$. HRMS (TOF MSES positive mode) $\mathrm{m} / \mathrm{z}$ calcd. for $\mathrm{C}_{16} \mathrm{H}_{22} \mathrm{NO}_{2}[\mathrm{MH}]+: 260.1651$; found : 260.1646

\section{N,N-Dibenzylbut-3-yn-1-amine 15a}

Colorless oil (20\%); $\mathrm{Rf}=0.7$ (PE/EtOAc: 95/5); ${ }^{1} \mathrm{H}$ NMR $(300 \mathrm{MHz}$ $\left.\mathrm{CDCl}_{3}\right): \delta=7.35-7.12(\mathrm{~m}, 10 \mathrm{H}, \mathrm{Ph}), 3.56\left(\mathrm{~s}, 4 \mathrm{H}, \mathrm{NCH}_{2} \mathrm{Ph}\right), 2.63(\mathrm{t}, J=$ $\left.7.4 \mathrm{~Hz}, 2 \mathrm{H}, \mathrm{NCH}_{2} \mathrm{CH}_{2}\right), 2.30$ (td, $J=7.4,2.4 \mathrm{~Hz}, 2 \mathrm{H}, \mathrm{NCH}_{2} \mathrm{CH}_{2}$ ), $1.86(\mathrm{t}, J$ $=2.6 \mathrm{~Hz}, 1 \mathrm{H}, \mathrm{CCH}) \mathrm{ppm} .{ }^{13} \mathrm{C} \mathrm{NMR}\left(75 \mathrm{MHz}, \mathrm{CDCl}_{3}\right): \delta=139.32\left(\mathrm{C}_{\mathrm{q}}\right)$, $128.79\left(\mathrm{C}_{\mathrm{Ar}}\right), 128.29\left(\mathrm{C}_{\mathrm{Ar}}\right), 127.03\left(\mathrm{C}_{\mathrm{Ar}}\right), 83.00(\mathrm{CCH}), 69.09(\mathrm{CCH})$, $58.10\left(\mathrm{NCH}_{2} \mathrm{Ph}\right), 52.06\left(\mathrm{NCH}_{2} \mathrm{CH}_{2}\right), 17.06\left(\mathrm{NCH}_{2} \mathrm{CH}_{2}\right)$ ppm. IR: vmax $=$ $3126,1609,731,696,638 \mathrm{~cm}^{-1}$. HRMS (TOF MSES positive mode) $\mathrm{m} / \mathrm{z}$ calcd. for $\mathrm{C}_{18} \mathrm{H}_{20} \mathrm{~N}[\mathrm{MH}]+$ : 250.1596 ; found : 250.1592 .

\section{((Pent-4-yn-1-yloxy)methanetriyl)tribenzene 16a}

White solid (64\%); Rf $=0.55$ (PE/EtOAc: $95 / 5) ;{ }^{1} \mathrm{H}$ NMR $(300 \mathrm{MHz}$, $\left.\mathrm{CDCl}_{3}\right): \delta=7.37$ (dd, $\left.J=5.2,3.4 \mathrm{~Hz}, 6 \mathrm{H}, \mathrm{Ar}\right), 7.28-7.07(\mathrm{~m}, 9 \mathrm{H}, \mathrm{Ar})$, 3.09 (t, $\left.J=6.1 \mathrm{~Hz}, 2 \mathrm{H}, \mathrm{CH}_{2}\right), 2.27\left(\mathrm{td}, J=7.3,2.6 \mathrm{~Hz}, 2 \mathrm{H}, \mathrm{CH}_{2}\right), 1.81$ (t, $J$ $=2.6 \mathrm{~Hz}, 1 \mathrm{H}, \mathrm{CCH}), 1.74\left(\mathrm{q}, \mathrm{J}=6.7 \mathrm{~Hz}, 2 \mathrm{H}, \mathrm{CH}_{2}\right) \mathrm{ppm} .{ }^{13} \mathrm{C} \mathrm{NMR}(75$ $\left.\mathrm{MHz}, \mathrm{CDCl}_{3}\right): \delta=144.31\left(\mathrm{C}_{\mathrm{q}}\right), 128.73\left(\mathrm{C}_{\mathrm{Ar}}\right), 127.77\left(\mathrm{C}_{\mathrm{Ar}}\right), 126.93\left(\mathrm{C}_{\mathrm{Ar}}\right)$, $86.43\left(\mathrm{C}_{\mathrm{q}}\right), 84.21\left(\mathrm{C}_{\mathrm{q}}\right), 68.43(\mathrm{CCH}), 61.98\left(\mathrm{CH}_{2}\right), 29.21\left(\mathrm{CH}_{2}\right), 15.62$ $\left(\mathrm{CH}_{2}\right)$ ppm. IR: vmax $=3296,1488,1448,1070,1014,744,705,635 \mathrm{~cm}$ . HRMS (TOF MSES positive mode) $\mathrm{m} / \mathrm{z}$ calcd. for $\mathrm{C}_{24} \mathrm{H}_{23} \mathrm{O}[\mathrm{MH}]+$ : 327.1749 ; found : 327.1747 . 


\section{3-Benzyl-5-(1H-tetrazol-5-yl)oxazolidin-2-one 25}

(Thionyl chloride procedure)

White solid (88\%); Mp: $129-131^{\circ} \mathrm{C} ; \mathrm{Rf}=0.1(\mathrm{DCM} / \mathrm{MeOH} / \mathrm{AcOH}$ 96/2/2); ${ }^{1} \mathrm{H}$ NMR (300 MHz, MeOD): $\delta=7.34-7.14(\mathrm{~m}, 5 \mathrm{H}, \mathrm{Ph}), 5.78(\mathrm{dd}, J=9.1$, $5.9 \mathrm{~Hz}, 1 \mathrm{H}, \mathrm{CHTet}$ ), 4.48 and 4.30 (two d, $J=14.9 \mathrm{~Hz}, 2 \mathrm{H}, \mathrm{NCH}_{2} \mathrm{Ph}$ ), $3.89(\mathrm{t}, J=9.2 \mathrm{~Hz}, 1 \mathrm{H}, \mathrm{NCHHCHTet}), 3.77(\mathrm{dd}, J=9.2,5.9 \mathrm{~Hz}, 1 \mathrm{H}$, NCHHCHTet) ppm. ${ }^{13} \mathrm{C}$ NMR (75 MHz, MeOD): $\delta=157.09\left(\mathrm{C}_{\mathrm{q}}\right), 155.97$ $\left(\mathrm{C}_{\mathrm{q}}\right), 134.47\left(\mathrm{C}_{\mathrm{q}}\right), 129.08\left(\mathrm{C}_{\mathrm{Ar}}\right), 128.45\left(\mathrm{C}_{\mathrm{Ar}}\right), 128.17\left(\mathrm{C}_{\mathrm{Ar}}\right), 66.31$ (CHTet), 48.60 ( $\left.\mathrm{NCH}_{2} \mathrm{CHTet}\right), 48.44\left(\mathrm{NCH}_{2} \mathrm{Ph}\right)$ ppm. IR: vmax $=1746,1436,1261$ 1053, 1029, $694 \mathrm{~cm}^{-1}$. HRMS (TOF MSES positive mode) $\mathrm{m} / \mathrm{z}$ calcd. for $\mathrm{C}_{11} \mathrm{H}_{12} \mathrm{~N}_{5} \mathrm{O}_{2}[\mathrm{MH}]+$ : 246.0994; found : 246.0991 .

\section{3-Benzyl-6-(1H-tetrazol-5-yl)-1,3-oxazinan-2-one 26}

(Thionyl chloride procedure)

White foam (70\%); Mp: $134-136^{\circ} \mathrm{C} ; \mathrm{Rf}=0.4(\mathrm{DCM} / \mathrm{MeOH} / \mathrm{AcOH} 96 / 4 / 2)$; ${ }^{1} \mathrm{H}$ NMR (300 MHz, MeOD): $\delta=7.32-7.13(\mathrm{~m}, 5 \mathrm{H}, \mathrm{Ph}), 5.83-5.69(\mathrm{~m}, 1 \mathrm{H}$ CHTet), 4.54 (s, 2H, NCH $2 \mathrm{Ph}$ ), 3.46-3.20 (m, 2H, NCH $\left.\mathrm{CH}_{2}\right), 2.60-2.29$ $\left(\mathrm{m}, 2 \mathrm{H}, \mathrm{NCH}_{2} \mathrm{CH}_{2}\right)$ ppm. ${ }^{13} \mathrm{C}$ NMR (75 MHz, MeOD): $\delta=154.64\left(\mathrm{C}_{\mathrm{q}}\right)$, $153.68\left(\mathrm{C}_{\mathrm{q}}\right), 135.30\left(\mathrm{C}_{\mathrm{q}}\right), 129.01\left(\mathrm{C}_{\mathrm{Ar}}\right), 128.23\left(\mathrm{C}_{\mathrm{Ar}}\right), 128.00\left(\mathrm{C}_{\mathrm{Ar}}\right), 70.71$ (CHTet), $53.04\left(\mathrm{NCH}_{2} \mathrm{Ph}\right), 42.81\left(\mathrm{NCH}_{2} \mathrm{CH}_{2}\right), 26.01\left(\mathrm{NCH}_{2} \mathrm{CH}_{2}\right) \mathrm{ppm}$. IR: $v \max =3034,2932,1668,1445,1266,1238,1135,725,694 \mathrm{~cm}^{-1}$. HRMS (TOF MSES positive mode) $\mathrm{m} / \mathrm{z}$ calcd. for $\mathrm{C}_{12} \mathrm{H}_{14} \mathrm{~N}_{5} \mathrm{O}_{2}[\mathrm{MH}]+$ : 260.1147 ; found : 260.1145

\section{5-((4'-Chloro-[1,1'-biphenyl]-4-yl)(methoxy)methyl)-1H-tetrazole 31}

(EDC procedure with methanol used as solvent instead of DCM) White solid $(60 \%)$; Mp: $189-191^{\circ} \mathrm{C}$ (dec.); $\mathrm{Rf}=0.25(\mathrm{DCM} / \mathrm{MeOH} / \mathrm{AcOH}$ 96/2/2); ${ }^{1} \mathrm{H}$ NMR (300 MHz, MeOD): $\delta=7.54$ (d, $J=8.3 \mathrm{~Hz}, 2 \mathrm{H}, \mathrm{Ar}$ ), 7.50 $(\mathrm{d}, J=8.6 \mathrm{~Hz}, 2 \mathrm{H}, \mathrm{Ar}), 7.40(\mathrm{~d}, J=8.3 \mathrm{~Hz}, 2 \mathrm{H}, \mathrm{Ar}), 7.32(\mathrm{~d}, J=8.6 \mathrm{~Hz}$, $2 \mathrm{H}, \mathrm{Ar}), 5.72$ (s, 1H, CHOMe), 3.35 (s, 3H, CHOMe) ppm. ${ }^{13} \mathrm{C}$ NMR (75 $\mathrm{MHz}, \mathrm{MeOD}): \delta=159.27\left(\mathrm{C}_{\mathrm{q}}\right), 141.83\left(\mathrm{C}_{\mathrm{q}}\right), 140.36\left(\mathrm{C}_{\mathrm{q}}\right), 138.19\left(\mathrm{C}_{\mathrm{q}}\right)$, $134.77\left(\mathrm{C}_{\mathrm{q}}\right), 130.01\left(\mathrm{C}_{\mathrm{Ar}}\right), 129.55\left(\mathrm{C}_{\mathrm{Ar}}\right), 128.88\left(\mathrm{C}_{\mathrm{Ar}}\right), 128.40\left(\mathrm{C}_{\mathrm{Ar}}\right), 77.66$ (CHOMe), 57.68 (Me) ppm. IR: vmax =1485, 1437, 1075, 805, $654 \mathrm{~cm}^{-1}$. HRMS (TOF MSES positive mode) $\mathrm{m} / \mathrm{z}$ calcd. for $\mathrm{C}_{15} \mathrm{H}_{14} \mathrm{CIN}_{4} \mathrm{O}[\mathrm{MH}]+$ : 301.0860; found : 301.0856 .

\section{3-Benzyl-5-(1-benzyl-1H-tetrazol-5-yl)oxazolidin-2-one and 3-benzyl-} 5-(2-benzyl-2H-tetrazol-5-yl)oxazolidin-2-one 32

Colorless oil (60\%); $\mathrm{Rf}=0.2$ (min.), 0.3 (maj.) (PE/EtOAc: 70/30); ${ }^{1} \mathrm{H}$ $\operatorname{NMR}\left(300 \mathrm{MHz}, \mathrm{CDCl}_{3}\right): \delta=7.34-7.14(\mathrm{~m}, 5 \mathrm{H}, \mathrm{Ph}), 5.78(\mathrm{dd}, J=9.1,5.9$ $\mathrm{Hz}, 1 \mathrm{H}, \mathrm{CH}$ Tet), 4.48 and 4.30 (two d, $J=14.9 \mathrm{~Hz}, 2 \mathrm{H}, \mathrm{NCH}_{2} \mathrm{Ph}$ ), 3.89 (t, $J=9.2 \mathrm{~Hz}, 1 \mathrm{H}, \mathrm{NCH} H \mathrm{HCHTet}), 3.77$ (dd, $J=9.2,5.9 \mathrm{~Hz}, 1 \mathrm{H}$, $\mathrm{NCH}$ HCHTet) ppm. ${ }^{13} \mathrm{C}$ NMR $\left(75 \mathrm{MHz}, \mathrm{CDCl}_{3}\right): \delta=163.91\left(\mathrm{C}_{\mathrm{q}}{ }^{\mathrm{M}}\right), 156.87$ $\left(\mathrm{C}_{\mathrm{q}}{ }^{\mathrm{M}}{ }^{(\mathrm{CO})}\right), 155.75\left(\mathrm{C}_{\mathrm{q}}{ }^{\mathrm{m}}{ }^{(\mathrm{CO})}\right), 151.37\left(\mathrm{C}_{\mathrm{q}}{ }^{\mathrm{m}}\right), 135.26\left(\mathrm{C}_{\mathrm{q}}\right), 134.64\left(\mathrm{C}_{\mathrm{q}}\right)$, $132.63\left(\mathrm{C}_{\mathrm{q}}\right), 132.59\left(\mathrm{C}_{\mathrm{q}}\right), 129.38\left(\mathrm{C}_{\mathrm{Ar}}\right), 129.32\left(\mathrm{C}_{\mathrm{Ar}}\right), 129.27\left(\mathrm{C}_{\mathrm{Ar}}\right), 129.15$ $\left(\mathrm{C}_{\mathrm{Ar}}\right), 129.06\left(\mathrm{C}_{\mathrm{Ar}}\right), 128.92\left(\mathrm{C}_{\mathrm{Ar}}\right), 128.60\left(\mathrm{C}_{\mathrm{Ar}}\right), 128.40\left(\mathrm{C}_{\mathrm{Ar}}\right), 128.26\left(\mathrm{C}_{\mathrm{Ar}}\right)$, $128.20\left(\mathrm{C}_{\mathrm{Ar}}\right), 128.15\left(\mathrm{C}_{\mathrm{Ar}}\right), 128.12\left(\mathrm{C}_{\mathrm{Ar}}\right), 66.03$ (C $\left.\mathrm{C}^{\mathrm{M}} \mathrm{HTet}\right), 64.57$ ( $\left.\boldsymbol{C}^{\mathrm{m}} \mathrm{HTet}\right)$, 57.22 (Tet $\boldsymbol{C}^{\mathrm{M}} \mathrm{H}_{2} \mathrm{Ph}$ ), 51.97 ( Tet $\left.\boldsymbol{C}^{\mathrm{m}} \mathrm{H}_{2} \mathrm{Ph}\right), 48.54\left(\mathrm{CH}_{2} \mathrm{NC}^{\mathrm{m}} \mathrm{H}_{2} \mathrm{Ph}\right), 48.47$ $\left(\mathrm{CH}_{2} \mathrm{NC}^{\mathrm{M}} \mathrm{H}_{2} \mathrm{Ph}\right), 48.00\left(\boldsymbol{C}^{\mathrm{M}} \mathrm{H}_{2} \mathrm{NCH}_{2} \mathrm{Ph}\right), 46.90\left(\boldsymbol{C}^{\mathrm{m}} \mathrm{H}_{2} \mathrm{NCH}_{2} \mathrm{Ph}\right)$ ppm. IR: vmax $=1745,1436,1261,1053,1030,694 \mathrm{~cm}^{-1}$. HRMS (TOF MSES positive mode) $\mathrm{m} / \mathrm{z}$ calcd. for $\mathrm{C}_{18} \mathrm{H}_{18} \mathrm{~N}_{5} \mathrm{O}_{2}[\mathrm{MH}]+$ : 336.1460 ; found : 336.1460 .

\section{Acknowledgements}

The University of Versailles St-Quentin-en-Yvelines, University Paris-Saclay and the CNRS are acknowledged for funding. PQ acknowledges l'École polytechnique for a PhD grant.
[1] E. W. Colvin, B. J. Hamill, J. Chem. Soc. Chem. Commun. 1973, 151 152.

[2] E. J. Corey, P. L. Fuchs, Tetrahedron Lett. 1972, 13, 3769-3772.

[3] D. Habrant, V. Rauhala, A. M. P. Köskinen, Chem. Soc. Rev. 2010, 39, 2007-2017.

[4] U. Weerasooriya, J. C. Gilbert, J. Org. Chem. 1979, 44, 4997-4999.

[5] G. J. Roth, B. Liepold, S. G. Müller, H. J. Bestmann, Synthesis, 2004, 59-62.

[6] D. F. Taber, S. Bai, P. F. Guo, Tetrahedron Lett. 2008, 49, 6904-6906.

[7] H. Behringer, M. Martner, Tetrahedron Lett. 1966, 7, 1663-1669.

[8] For examples of generation of vinyl carbenes from alpha cyano mesylates in a carbohydrate series, see: a) M. J. Pérez-Pérez, M. J. Camarasa, Tetrahedron, 1994, 50, 7269-7282. b) A. Nguyen Van Nhien, R. Leon, D. Postel, M. Carmo-Carreiras, A. G. Garcia, J. MarcoContelles, J. Carbohydr. Chem. 2005, 24, 369-377. c) R. Cordonnier, A. Nguyen Van Nhien, E. Soriano, J. Marco-Contelles, Tetrahedron, 2010, 66, 736-742. d) A. N. Van Nhien, R. Cordonnier, M. D. Le Bas, S. Delacroix, E. Soriano, J. Marco-Contelles, D. Postel, Tetrahedron 2009, 65, 9378-9394. e) A. N. Van Nhien, E. Soriano, J. Marco-Contelles, D. Postel, Carbohydrate Research. 2009, 344, 1605-1611.

[9] D. J. Wardrop, J. P. Komenda, Org. Lett. 2012, 14, 1548-1551. For an isolated example reporting the trapping of a vinylidene carbene generated from an AHT, see: Y. Wang, M. E. Muratore, Z. Rong, A. M. Echavarren, Angew. Chem. Int. Ed. 2014, 53, 14022-14026.

[10] K. Wright, P. Quinodoz, B. Drouillat, F. Couty, Chem. Commun. 2017, 53, 321-323.

[11] a) B. E. Fischer, A. J. Thomson, J. P. Horwitz, J. Org. Chem. 1959, 24, 1640-1654. b) C. David Jones, M. A. Winter, K. S. Hirsch, N. Stamm, H. M. Taylor, H. E. Holden, J. D. Davenport, E. IV. Krumkalns, R. G. Surh, J. Med. Chem. 1990, 33, 416-429. c) B. C. H. Mat, A. D. Abell, Tetrahedron Lett. 2001, 42, 5641-5644.

[12] By nucleophilic addition of lithiated tetrazoles, see: a) Y. Satoh, J. Moliterny, Synlett, 1998, 528-530. See also ref 8. By Ugi reactions, see a) T. Yue, M. -X. Wang, D. -X. Wang, J. Zhu, Angew. Chem. Int. Ed. 2008, 47, 9454-9457. b) A. Chandgude, A. Dömling, Green Chem. 2016, 18, 3718-3721. c) Z. -L Ren, J. -C Liu, M. -W. Ding, Synthesis, 2017, 49, 745-754.

[13] P. Quinodoz, C. Lo, M. Kletskii, O. Burov, J. Marrot, F.Couty Organic Chemistry Frontiers, 2015, 2, 492-496.

[14] a) I. Cristiano, F. Gomez-Zavaglia, J. Phys. Chem. A, 2010, 114 13076-13085. b) A. Vasudevan, Z. Ji, R.R. Frey, C. K. Wada, D. Steinman, H. R. Heyman, Y. Guo, M. L. Curtin, J. Guo, J. Li, L. Pease, K. B. Glaser, P. A. Marcotte, J. J. Bouska, S. K. Davidsen, M. R. Michaelides, Bioorg. Med. Chem. Lett. 2003, 13, 3909-3913. c) A. Johansson, A. Poliakov, E. Åkerblom, K. Wiklund, G. Lindeberg, S. Winiwarter, U.H. Danielson, B. Samuelsson, A. Hallberg, Bioorg. Med. Chem. 2003, 11, 2551-2568.

[15] H. Yoneyama, M. Numata, K. Uemura, Y. Usami, S. Harusawa, J. Org Chem. 2017, 82, 5538-5556.

[16] Addition of a base (DIPEA) able to neutralize the tetrazole upon reaction with DIC inhibits production of the alkyne.

Keywords: ethynylation $\cdot$ tetrazoles $\cdot$ vinyl carbenes. 
Entry for the Table of Contents (Please choose one layout)

\section{FULL PAPER}

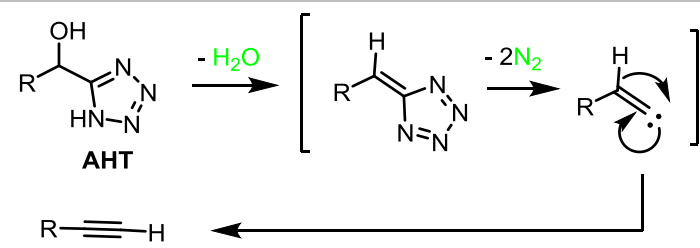

This article focuses on the dehydration of alpha hydroxy tetrazoles (AHTs), leading to ethynyl moieties via a vinyl carbene. The mechanism is scrutinized, through either examination of the substrate and/or dehydrating agent scope, or through $\mathrm{PCM} / \mathrm{PBE} / 6-31++\mathrm{G}(\mathrm{d}, \mathrm{p})$ quantum chemical calculations in dichloromethane. This underrated transformation appears to be a viable alternative to the existing methods to transform an aldehyde into an alkyne.
Alpha hydroxy tetrazoles as latent ethynyl moieties: a mechanistic investigation

Pierre Quinodoz, Karen Wright, Bruno Drouillat, Mikhail E. Kletskii, Oleg N. Burov, Anton V. Lisovin, and François Couty *

Page No. - Page No. 